\title{
WILEY-VCH
}

DOI: 10.1002/ ((please add manuscript number))

Article type: Full Paper

\section{Toward the Sustainable Lithium Metal Batteries with a New Electrolyte Solvation Chemistry}

Seon Hwa Lee, Jang-Yeon Hwang, Jun Ming, Zhen Cao, Hoang Anh Nguyen, Hun-Gi Jung, Jaekook Kim, and Yang-Kook Sun*

S. H. Lee, H. A. Nguyen, Prof. Y.-K. Sun

Department of Energy Engineering,

Hanyang University,

Seoul 04763, Republic of Korea

Email: yksun@hanyang.ac.kr

Prof. J.-Y. Hwang, Prof. J. Kim

Department of Materials Science and Engineering,

Chonnam National University,

Gwangju, 61186, Republic of Korea

Prof. J. Ming

State Key Laboratory of Rare Earth Resource Utilization,

Changchun Institute of Applied Chemistry, CAS,

Changchun, 130022, P. R. China

Dr. Z. Cao

Physical Sciences and Engineering Division,

King Abdullah University of Science and Technology,

Thuwal 23955-6900, Saudi Arabia

H.-G. Jung

Center for Energy Convergence Research, Green City Technology Institute,

Korea Institute of Science and Technology,

Seoul, 136-791, Republic of Korea

Keywords: lithium metal battery, high energy density, electrolyte solvation structure, additive, Li-Mg alloy 


\title{
WILEY-VCH
}

\begin{abstract}
Herein, we introduce a new solvation strategy enabled by $\mathrm{Mg}\left(\mathrm{NO}_{3}\right)_{2}$, which can be dissolved directly as $\mathrm{Mg}_{2}+$ and $\mathrm{NO}_{3}$ - ions in the electrolyte to change the $\mathrm{Li}+$ ion solvation structure and greatly increase interfacial stability in Li-metal batteries (LMBs). This is the first report of introducing $\mathrm{Mg}\left(\mathrm{NO}_{3}\right)_{2}$ additives in an ester-based electrolyte composed of ternary salts and binary ester solvents to stabilize LMBs. In particular, we find that $\mathrm{NO}_{3}$ - efficiently forms a stable solid electrolyte interphase (SEI) through an electrochemical reduction reaction, along with the other multiple anion components in the electrolyte. The interaction between $\mathrm{Li}+$ and $\mathrm{NO}_{3}$ - and coordination between $\mathrm{Mg}_{2+}$ and solvent molecules greatly decrease the number of solvent molecules surrounding the $\mathrm{Li}+$, which leads to facile $\mathrm{Li}+$ de-solvation during plating. In addition, $\mathrm{Mg}_{2}$ ions are reduced to $\mathrm{Mg}$ via a spontaneous chemical reaction on the Li metal surface and subsequently form a lithiophilic Li-Mg alloy, suppressing lithium dendritic growth. The unique solvation chemistry of $\mathrm{Mg}\left(\mathrm{NO}_{3}\right)_{2}$ enables long cycling stability and high efficiency of the Li-metal anode and ensures an unprecedented lifespan for a practical pouchtype LMB with high-voltage Ni-rich NCMA73 cathode even under constrained conditions.
\end{abstract}

\section{Introduction}

Pursuing higher energy density and longer lifetime in rechargeable batteries is critical for increasing the attractiveness of electric vehicles (EVs). In recent years, nickel-rich $\mathrm{Li}\left[\mathrm{Nix}_{\mathrm{x}} \mathrm{CoyMn}_{1-\mathrm{x}-\mathrm{y}}\right] \mathrm{O}_{2}(\mathrm{NCM})$ layered cathode materials $(\mathrm{x} \geq 0.6)$ are of special interest for lithium-ion batteries (LIBs).[1-4] This is because they can deliver high specific capacity (> 180 mAh g-1) without the need to increase the charging potential to levels that go beyond the stable operating voltage window. As a cathode counterpart, graphite has been the most commercially successful anode material for LIBs due to its low material cost and reduction potential $\left(\sim 0.05 \mathrm{~V}\right.$ vs $\left.\mathrm{Li}_{/} / \mathrm{Li}_{+}\right)$. However, graphite anodes limit the enhancement of energy density and charging rate due to their low theoretical capacity (375 $\mathrm{mAh} \mathrm{g-1)} \mathrm{and} \mathrm{staged}$ 


\section{WILEY-VCH}

lithium (de) intercalation mechanism, making it difficult to meet the expectation of cuttingedge electronic devices.[5,6] Hence, the development of metallic lithium as an anode is attracting great attention because of its exceptionally high specific capacity (3,860 mAh g-1), small gravimetric density $(0.534 \mathrm{~g} \mathrm{~cm}-3)$, and low negative electrochemical potential $(-3.040$ V vs the standard hydrogen electrode).[7-9] Therefore, theoretically, rechargeable batteries using Li metal (LMB) and a nickel-rich NCM cathode can easily surpass the energy density of state-of-the-art commercial LIBs using graphite, thereby achieving the goal of 300-400 Wh kg-1 for LIBs.[10]

However, thermodynamic instability between Li metal and electrolyte during the charging process always causes an unavoidable parasitic process, wherein the electrolyte spontaneously reacts with the Li anode to deplete the electrolyte, thicken the SEI and induce dendritic growth of $\mathrm{Li}$, resulting in low Coulombic efficiency (CE), rapid capacity drop, and safety concerns.[7,11,12] To alleviate these weaknesses of LMBs, many efforts, including electrolyte engineering,[4,13] use of a 3D host structure,[14,15] and artificial SEI engineering, $[16,17]$ are being widely explored. Among these strategies, developing new electrolytes enabling high-efficiency for Li-metal and stable high-voltage operation is the most effective and promising.[13,18] This is because we can modulate the solvation sheath of Li ions to enhance the stability of SEI significantly[18] without complicated and time-consuming processes. On the other hand, the addition of certain functional additives in electrolytes can be beneficial for forming stable SEI and dense Li deposition. As an example, highly stable Limetal was enabled by regulating the solvation of lithium ions using fluoroethylene carbonate (FEC) and/or $\mathrm{LiNO}_{3}$ additive in an ester-based electrolyte.[19,20] The $\mathrm{NO}_{3}$ - from $\mathrm{LiNO}_{3}$ can participate in the solvation sheath of $\mathrm{Li}_{+}$in the electrolyte and generate $\mathrm{LiF}$ and/or $\mathrm{LiN}_{\mathrm{x}} \mathrm{O}_{\mathrm{y}}$ that are generally known to improve SEI stability and the uniformity of lithium deposition. However, $\mathrm{LiNO}_{3}$ as an additive still poses several challenges in practice, due to a rather limited solubility in ester-based electrolytes, resulting in poor LMB performance matched 


\section{WILEY-VCH}

with a high voltage NCM cathode.[20,21] In addition, the effects of $\mathrm{LiNO}_{3}$ in the electrolyte might need to be re-considered from a new angle in the $\mathrm{Li}+$ ion solvation structure, as well as its effect on forming SEI.

In this study, we introduce a completely new additive, $\mathrm{Mg}\left(\mathrm{NO}_{3}\right)_{2}$, in an ester-based electrolyte for the first time. This is a breakthrough discovery because $\operatorname{Mg}\left(\mathrm{NO}_{3}\right)_{2}$ can be dissolved directly as $\mathrm{Mg}_{2}+$ and $\mathrm{NO}_{3}$ - ions in the electrolyte even to a high concentration of 0.1 M, which was completely unexpected. This has never been previously reported for metal nitrates, and it is totally different from the behavior of $\mathrm{LiNO}_{3}$. More importantly, we find that the interfacial stability of lithium metal and electrolyte can be improved significantly in LMBs when $\mathrm{Mg}\left(\mathrm{NO}_{3}\right)_{2}$ is added. We confirmed a novel synergy effect in solvation chemistry between the $\mathrm{Mg}_{2}+$ and $\mathrm{NO}_{3}$ - that can result in high performance of LMBs. Besides the positive effect of $\mathrm{NO}_{3}$ - ion for forming stable $\mathrm{SEI}$, the $\mathrm{NO}_{3}$ - ion is also beneficial for desolvation of the $\mathrm{Li}_{+}$for good lithium deposition. The strong interaction between $\mathrm{Li}_{+}$and $\mathrm{NO}_{3}$ and coordination between $\mathrm{Mg}_{2+}$ and solvent molecules can decrease the number of solvent molecules surrounding the $\mathrm{Li}_{+}$, leading to facile $\mathrm{Li}+$ de-solvation during plating. In addition, some portion of the $\mathrm{Mg}_{2+}$ is also reduced to $\mathrm{Mg}$ metal via spontaneous chemical reaction on the Li metal surface and subsequently forms a lithiophilic Li-Mg alloy, suppressing lithium dendritic growth. As a result, the unique solvation chemistry of $\mathrm{Mg}\left(\mathrm{NO}_{3}\right)_{2}$ enables long cycling stability and high efficiency of the Li-metal anode, ensuring an unprecedented lifespan of a practical pouch-type LMB with a high-voltage Ni-rich NCMA73 cathode even under several constraints.

\section{Result \& Discussion}

\subsection{Features of additives for lithium deposition}

The introduction of $\mathrm{Mg}\left(\mathrm{NO}_{3}\right)_{2}$ as an additive in ester-based electrolytes is one of the most important discoveries in this study, where an electrolyte consisting of $0.8 \mathrm{M}$ lithium 


\section{WILEY-VCH}

bis(trifluoro methanesulfonyl)imide(LiTFSI), $0.2 \mathrm{M}$ difluoro(oxalato)borate (LiDFOB), 0.05 M LiPF6 in ethylmethyl carbonate/fluoroethylene carbonate (EMC/FEC) $(\mathrm{v} / \mathrm{v}=3: 1)$ was used as the baseline electrolyte.[4] This is the only multivalent metal nitrate that could be dissolved in the ester-based electrolyte (Figure S1). The positive effect of $\mathrm{Mg}\left(\mathrm{NO}_{3}\right)_{2}$ can be analyzed directly by the plated lithium, where $\mathrm{Li} \mid \mathrm{Li}$ symmetric cells were assembled and tested at a constant current density of $1.8 \mathrm{~mA} \mathrm{~cm}-2$ and a capacity loading of $1.8 \mathrm{mAh} \mathrm{cm}-2$. The structural evolution of the plated lithium as a function of deposit time $(5,10$, and $60 \mathrm{~min})$ was observed by SEM (Figure 1, Figure S2). We found that random lithium dendrite was deposited vertically at first (after 5-10 min) in the baseline electrolyte; then, at the end of the deposit time (after $60 \mathrm{~min}$ ), the deposited Li was loosely aggregated, giving rise to a porous structure with a high surface area, which might increase the electrolyte consumption and promote continuous growth of $\mathrm{Li}$ dendrites. In contrast, in the case of the electrolyte with 0.1 $\mathrm{M} \mathrm{Mg}\left(\mathrm{NO}_{3}\right)_{2}$ additive, we found that spherical lithium was deposited after 3 min. This $\mathrm{Li}$ deposit behavior and morphology was retained after $10 \mathrm{~min}$, where the Li particles grew in a planar direction to cover the Li foil surface. Finally, a comparatively smooth and dense deposit morphology was obtained without dendrite formation at the end of the deposit time (after $60 \mathrm{~min}$ ). A cross-sectional SEM image of the cycled anodes with the $\mathrm{Mg}\left(\mathrm{NO}_{3}\right)_{2}$ additive is in good agreement with the surface images of the deposited Li morphology on the anode surface. The electrolyte with $0.05 \mathrm{M} \mathrm{Mg}\left(\mathrm{NO}_{3}\right)_{2}$ additive showed similar $\mathrm{Li}$ deposit morphology at the end of the deposit time (Figure S1), but it has relatively low thickness compared to the electrolyte containing $0.1 \mathrm{M} \mathrm{Mg}\left(\mathrm{NO}_{3}\right)_{2}$. This comparative result demonstrates that the $\operatorname{Mg}\left(\mathrm{NO}_{3}\right)_{2}$ additive is efficient for suppressing the formation of lithium dendrites.

\subsection{Electrochemical performance}




\section{WILEY-VCH}

For practical LMBs, electrochemical stability and good compatibility with the Li anode are very important properties of the electrolyte solution. Firstly, an asymmetry $\mathrm{Li} \mid \mathrm{Cu}$ cell was studied to evaluate the superiority of the developed electrolyte. The cell was (dis-)charged at a current density of $2.0 \mathrm{~mA} \mathrm{~cm}-2$ and the areal capacity in each discharge process was controlled at $2.0 \mathrm{mAh} \mathrm{cm}-2$. The typical voltage vs. capacity profiles at the $1 \mathrm{st}, 50_{\mathrm{th}}$ and $100_{\mathrm{th}}$ cycle are displayed in Figure 2a-b and Figure S3, where significant differences can be observed upon cycling depending on the concentration of $\mathrm{Mg}\left(\mathrm{NO}_{3}\right)_{2}$ additive. In detail, the $\mathrm{Li}$ | $\mathrm{Cu}$ cell using an electrolyte containing $0.1 \mathrm{M} \mathrm{Mg}\left(\mathrm{NO}_{3}\right)_{2}$ demonstrates the lowest overpotential (baseline: $89.5 \mathrm{mV}$; $0.05 \mathrm{M} \mathrm{Mg}\left(\mathrm{NO}_{3}\right) 2: 46.0 \mathrm{mV}$; $0.1 \mathrm{M} \mathrm{Mg}\left(\mathrm{NO}_{3}\right) 2: 43.2 \mathrm{mV}$ ), the best cycle stability, and the highest Li plating/stripping reversibility. To further verify the cycling stability of the Li-metal, galvanostatic cycling was performed using a $\mathrm{Li} \mid \mathrm{Li}$ symmetric cell at $1.8 \mathrm{mAh} \mathrm{cm-2} \mathrm{(2} \mathrm{h} \mathrm{per} \mathrm{cycle),} \mathrm{as} \mathrm{shown} \mathrm{in} \mathrm{Figure} 2 \mathrm{c}$ and Figure S4. The cell using the baseline electrolyte shows poor cycling stability (410 h). The depositing and stripping stability was improved upon adding $0.05 \mathrm{M} \mathrm{Mg}\left(\mathrm{NO}_{3}\right)_{2}$. The most dramatic improvement was observed with the $0.1 \mathrm{M} \mathrm{Mg}\left(\mathrm{NO}_{3}\right)_{2}$-containing electrolyte. These results demonstrate that $\mathrm{Mg}\left(\mathrm{NO}_{3}\right)_{2}$ can suppress the side reaction between $\mathrm{Li}$ and the electrolyte, thereby stabilizing LMB performance.

The superiority of the electrolyte containing $\mathrm{Mg}\left(\mathrm{NO}_{3}\right)_{2}$ was further confirmed in LMBs when the lithium was coupled with a high voltage Ni-rich cathode of full concentration gradient $\mathrm{Li}\left[\mathrm{Ni} 0.73 \mathrm{Co} 0.05 \mathrm{Mn} 0.15 \mathrm{Al}_{0.02}\right] \mathrm{O}_{2}$ (i.e., $\mathrm{Li} \mid \mathrm{NCMA73}$ ), which is a promising cathode for pursuing high-energy and high-power Li-metal batteries. It should be noted that the capability in LMB applications of the gradient Ni-rich NCMA73 cathode used in this study has already been proved because of its chemically and structurally stable features. The comparative performance of $\mathrm{Li} \mid \mathrm{NCMA73}$ batteries with and without $\mathrm{Mg}\left(\mathrm{NO}_{3}\right)_{2}$ additive is summarized in Figure 3, where the designed areal capacity is as high as $2.0 \mathrm{mAh} \mathrm{cm-2} \mathrm{with} \mathrm{a} \mathrm{cut-off} \mathrm{voltage}$ of 2.7-4.3 V. Firstly, we find that both Li | NCMA73 batteries deliver the same initial charge- 


\section{WILEY-VCH}

discharge capacity with a high Coulombic efficiency (CE) of 96\%, indicating the absence of side-reactions when using $\mathrm{Mg}\left(\mathrm{NO}_{3}\right)_{2}$ additive in the electrolyte (Figure S5). Then, the $\mathrm{Li} \mid$ NCMA73 battery using the $\mathrm{Mg}\left(\mathrm{NO}_{3}\right)_{2}$ modified electrolyte exhibits a marked improvement in cycling performance compared to a battery using the baseline electrolyte (Figure 3a). In detail, the Li I NCMA73 battery suffers from a continuous capacity fade, where fluctuation of the CE was observed during cycling. The fluctuating value of CE lower or higher than $100 \%$ indicates incomplete stripping or plating of $\mathrm{Li}_{+}$ions from the $\mathrm{Li}$ metal anode and possible dendritic growth of $\mathrm{Li}$ on the anode surface.[22] As a result, the Li | NCMA73 battery with baseline electrolyte shows end-of-life at the 600th cycle; good cycle performance can be maintained up to 150 cycles. In contrast, the Li | NCMA73 battery with electrolyte containing $\mathrm{Mg}\left(\mathrm{NO}_{3}\right)_{2}$ demonstrates excellent cycle performance and stable $\mathrm{CE}$ (over 99.7\%), where the capacity retention is as high as $80 \%$ after 1000 cycles. Note that an inferior cycle performance is observed when the $\operatorname{Mg}\left(\mathrm{NO}_{3}\right)_{2}$ concentration is reduced to $0.05 \mathrm{M}$, demonstrating that sufficient $\mathrm{Mg}\left(\mathrm{NO}_{3}\right)_{2}$ is necessary to guarantee the cycling stability of Li | NCMA73 battery (Figure S6). The effect of $\operatorname{Mg}\left(\mathrm{NO}_{3}\right)_{2}$ additive was further verified under fast chargingdischarging conditions (Figure 3b). A faster-discharging rate can estimate the power density of LIBs, which is significant for practical applications. We find that a discharge capacity can be achieved as high as $150 \mathrm{mAh}$ g-1 at a rate of $7 \mathrm{C}$ when $0.1 \mathrm{M} \mathrm{Mg}\left(\mathrm{NO}_{3}\right)_{2}$ is added. In contrast, the capacity of the Li $\mid$ NCMA73 battery is only about $50 \mathrm{mAh} \mathrm{g-1} \mathrm{without} \mathrm{the}$ $\operatorname{Mg}\left(\mathrm{NO}_{3}\right)_{2}$. Besides, the better cycle performance of $\mathrm{Li} \mid \mathrm{NCMA73}$ battery was further confirmed in the $\mathrm{Mg}\left(\mathrm{NO}_{3}\right)_{2}$ modified electorlyte at the higher current rate (i.e., $4 \mathrm{~mA} \mathrm{~cm}$-2)

\section{(Figure S7).}

To verify the application of $0.1 \mathrm{M} \mathrm{Mg}\left(\mathrm{NO}_{3}\right)_{2}$ modified electrolytes in realistic test conditions, we further fabricated and tested scaled-up pouch-type Li | NCMA73 batteries. A relatively lenient E/C (i.e. mass ratio of amount of electrolyte /cell capacity, g Ah-1) ratio of 27 was used in pouch-type Li $\mid$ NCMA73 batteries at first. The initial charge-discharge 


\section{WILEY-VCH}

capacities of the pouch-type batteries were virtually identical to those of coin-type batteries, showing good compatibility and reproducibility of $\mathrm{Mg}\left(\mathrm{NO}_{3}\right)_{2}$ modified electrolyte in the scaled-up practical batteries. The pouch-type Li $\mid$ NCMA73 battery with $\mathrm{Mg}\left(\mathrm{NO}_{3}\right)_{2}$ additive delivers unprecedented stable cycle performance up to 1300 cycles with a capacity retention of $80 \%$ (Figure 3c). Notably, compared with previously reported pouch-type LMB using carbonate-based electrolyte (Table 1),[19, 23-30] the proposed strategy manifested great competitiveness in terms of long-term cycling. Particularly, the positive effect of $\operatorname{Mg}\left(\mathrm{NO}_{3}\right)_{2}$ additive was also confirmed in LiPF6 salt-based electrolyte (Figure S8), which is the most commonly used as the salt in commercial LIBs. Thus, our discovery is significant for the realization of $\mathrm{LMB}$, because the newly designed $\mathrm{Mg}\left(\mathrm{NO}_{3}\right)_{2}$ modified electrolyte is competent for most commercialized lithium-ion batteries those used carbonate-based electrolytes.

\subsection{Electrolyte analysis}

The unique solubility of $\mathrm{Mg}\left(\mathrm{NO}_{3}\right)_{2}$ in ester-based electrolyte opens the door to unique possibilities in applications. Although the nitrate anion $\left(\mathrm{NO}_{3}-\right)$ demonstrates a pronounced effect on the morphology and reversibility of Li deposition in lithium batteries, its application in ester-based electrolyte is seriously limited due to its low solubility.[20,21] Fortunately, we discovered that only $\mathrm{Mg}\left(\mathrm{NO}_{3}\right)_{2}$ can be dissolved directly in $\mathrm{EMC} / \mathrm{FEC} \mathrm{(v/v=3:1)} \mathrm{solvent} \mathrm{up} \mathrm{to}$ 0.1 M concentration, forming a transparent electrolyte (Figure $4 \mathrm{a}-\mathrm{c}$ ). The $\mathrm{Li}+$ solvation structure and the state of the solvent might be changed due to solvation of $\operatorname{Mg}\left(\mathrm{NO}_{3}\right)_{2}$ in the electrolyte, which can be analyzed by ${ }_{13} \mathrm{C}-\mathrm{NMR}$ analysis (Figure 4d-h). The chemical shift of ${ }_{13} \mathrm{C}$ in the solvent and anions gradually move to lower ppm values when $\mathrm{Mg}\left(\mathrm{NO}_{3}\right)_{2}$ is added to the electrolyte, demonstrating a lower extra-nuclear electron cloud density on the carbon atoms. This result confirms the capability of $\mathrm{Mg}\left(\mathrm{NO}_{3}\right)_{2}$ to change the situation of the solvent, which means the situation of $\mathrm{Li}+$ solvation structure was also changed accordingly. Further evidence is found in the Raman spectrum of the solvent (Figure 5a). Here we find that the 


\section{WILEY-VCH}

proportion of solvated EMC and FEC in the baseline electrolyte is gradually increased as $\mathrm{Mg}\left(\mathrm{NO}_{3}\right)_{2}$ is added at 0.05 and $0.1 \mathrm{M}$. This is likely because the interaction between $\mathrm{Li}+$ and $\mathrm{NO}_{3}$ - is preferable, and the $\mathrm{NO}_{3}$ - replaces some of the solvent molecules within the first solvation shell. In addition, the added $\mathrm{Mg}_{2+}$ can coordinate with the solvent, which would also reduce the number of solvent molecules surrounding the $\mathrm{Li}+$. From the ${ }_{13} \mathrm{C}-\mathrm{NMR}$ and Raman data, we propose a $\mathrm{Li}+$ solvation structure with $\mathrm{Mg}\left(\mathrm{NO}_{3}\right)_{2}$ added to the baseline electrolyte as depicted in Figure 5b-d.

To verify the details of $\mathrm{Li}_{+}$solvation structure and our speculations based on experimental results, classical molecular dynamics (MD) simulations were further conducted and the results are illustrated in Figure 5e-j. The modified $\mathrm{Li}_{+}$solvation structure obtained from ${ }_{13} \mathrm{C}-\mathrm{NMR}$ and Raman spectra data shows good agreement with the simulation results, indicating that both $\mathrm{Mg}_{2}$ and $\mathrm{NO}_{3}$ - ions greatly change the $\mathrm{Li}+$ solvation structure. It should be noted that once $\mathrm{Mg}\left(\mathrm{NO}_{3}\right)_{2}$ is dissolved in the ester-based electrolyte solution, the $\mathrm{NO}_{3}$ - can replace solvent molecules around the $\mathrm{Li}+$. Such a replacement of solvent by the $\mathrm{NO}_{3}$ - anion is important because the $\mathrm{Li}+$ can be de-solvated much more easily and more efficiently from the new solvation structure. This is because the $\mathrm{NO}_{3}$ - anions can be expelled readily from the $\mathrm{Li}+$ solvation structure under the electric-field on the interface but still closer than solvent, where the $\mathrm{Li}_{+}$is easier to be reduced (i.e., Li deposition) on the anode after accepting the electron (Figure 5f). This could facilitate the Li plating/stripping reaction, preventing dendritic growth of $\mathrm{Li}$ and improving Coulombic efficiency (CE). Moreover, the $\mathrm{Mg}_{2+}$ can coordinate with the solvent, which means the solvent number around the $\mathrm{Li}+$ could be reduced further. Then, the solvated $\mathrm{Li}+$ would be much more easily de-solvated and plated in the plating process.

\subsection{SEI analysis}

In addition to the solvation structure, the formation of a stable SEI on the Li anode surface is also very important for Li plating/stripping kinetics. In general, the main components of the 


\section{WILEY-VCH}

SEI are derived from the reduction products between the electrolyte and Li metal anode. Hence, preferential decomposition products from solvents and anions in the solvation sheath compose the main components of the SEI. The key feature of $\mathrm{Mg}\left(\mathrm{NO}_{3}\right)_{2}$-containing electrolyte is the presence of $\mathrm{Mg}_{2+} / \mathrm{NO}_{3}$ - ions compared to the baseline electrolyte. Therefore, we can hypothesize that the $\mathrm{Li}+$ solvation structure changes by the addition of $\mathrm{Mg}\left(\mathrm{NO}_{3}\right)_{2}$ to the baseline electrolyte and forms different components in the SEI. Three different $\mathrm{Li} \mid \mathrm{Li}$ symmetric cells containing (1) baseline electrolyte, (2) added $0.05 \mathrm{M} \mathrm{Mg}\left(\mathrm{NO}_{3}\right)_{2}$, and (3) added $0.1 \mathrm{M} \mathrm{Mg}\left(\mathrm{NO}_{3}\right)_{2}$ were assembled to analyze their respective SEI layers. The SEI accumulated directly on the Li metal after the first deposition and was then analyzed by using X-ray photoelectron spectroscopy (XPS) measurements (Figure 6).

First, we found the presence of $\mathrm{Mg}$ species in the SEI when using $0.05 \mathrm{M}$ and $0.1 \mathrm{M}$ $\operatorname{Mg}\left(\mathrm{NO}_{3}\right)_{2}$-containing electrolytes, which implies that the $\mathrm{Mg}_{2+}$ ion contributes to changing the surface of the Li metal anode during the electrochemical plating process. Details are discussed later. The other critical difference lies in the significant variations in the elemental composition of the SEI layers. As $\mathrm{Mg}\left(\mathrm{NO}_{3}\right)_{2}$ is added, the portions of $\mathrm{C}$ and $\mathrm{O}$ content are decreased while the portions of F 1s, B 1s, S 2p and N 1s content are increased (Figure 6a). From this it can be deduced that the SEI layer formed by $\operatorname{Mg}\left(\mathrm{NO}_{3}\right)_{2}$-containing electrolyte has contributions from a reduction in salt or additive content rather than solvent molecules; this phenomenon could be attributed to the decreased average number of solvent around the $\mathrm{Li}+$ and anions as adding the $\operatorname{Mg}\left(\mathrm{NO}_{3}\right)_{2}$. These results are well matched with a previous report dealing with the relationship between free solvent molecules and Li metal stability.[31] Peaks at $684.8,685.2,686.4$, and $688.1 \mathrm{eV}$ corresponding to LiF, B-F, P-F, and C-F compounds, respectively, are observed in the $\mathrm{F} 1 \mathrm{~s}$ spectra.[4,32] It is interesting to note that as the concentration of $\operatorname{Mg}\left(\mathrm{NO}_{3}\right)_{2}$ additive in the electrolyte baseline increases, the fraction of oxalate and B-F compounds gradually increases (Figure 6b, Figure S9a-c). This is also supported by a higher peak intensity from Li-S/S-S compounds in the SEI induced by the 


\section{WILEY-VCH}

TSFI- upon increasing the concentration of $\mathrm{Mg}\left(\mathrm{NO}_{3}\right)_{2}$ additive (Figure S9d-f). In the $\mathrm{N} 1 \mathrm{~s}$ spectra, peaks at 398.4 and $400.5 \mathrm{eV}$ corresponding to $\mathrm{Li}-\mathrm{N}$ and $\mathrm{N}-\mathrm{S}$ compounds, respectively, were also observed for all the samples owing to decomposition of TFSI- on the Li metal surface.[3,21] In particular, an N-O compound generated by the reduction of the $\mathrm{NO}_{3}$ - anion is observed in the $0.05 \mathrm{M}$ and $0.1 \mathrm{M} \mathrm{Mg}\left(\mathrm{NO}_{3}\right)_{2}$ samples; generally, the presence of $\mathrm{N}-\mathrm{O}$ in SEI could help to enhance the uniformity of lithium deposition (Figure 6c). From the data, we can conclude that $\mathrm{Mg}_{2+} / \mathrm{NO}_{3}$ - can mitigate the solvent decomposition because it can decrease the number of coordinated solvents around cations. This is desired because the organic compounds in SEI (i.e., organic compounds-dominated SEI) can be reduced. Meanwhile, the anions (e.g., TFSI-, DFOB-, PF6-) is slightly easier to be decomposed in this condition, because the protection capability of solvent for anions can be decreased as decreasing the number of coordinated solvents, thus giving rise to more $\mathrm{LiF}$ and $\mathrm{LiN}_{\mathrm{x}} \mathrm{O}_{\mathrm{y}}$ in the SEI (i.e., inorganic compounds-dominated SEI). This synergy effect is positive. This is because the inorganic compounds-dominated SEI can not only protect the lithium metal but also can facilitate the transportation of $\mathrm{Li}+$ for the plating/stripping.

\subsection{Effect of $\mathrm{Mg}_{2+}$}

As well as looking into the effect of $\mathrm{NO}_{3-}$, we further investigated the effect of the $\mathrm{Mg}_{2+}$ ion on forming SEI when $\mathrm{Mg}\left(\mathrm{NO}_{3}\right)_{2}$ was added into the baseline electrolyte (Figure 7, Figure S10). In the proposed electrolyte with both $\mathrm{Li}$ and $\mathrm{Mg}$ salts, the dissociated $\mathrm{Mg}_{2+}$ ions should be readily reduced to metallic $\mathrm{Mg}$ by metallic lithium (i.e., $\mathrm{Mg}_{2+}+\mathrm{Li}_{\text {electrode }} \rightarrow \mathrm{Li}_{+}+$ $\mathrm{Mg} / \mathrm{Li}$ electrode $)$ because $\mathrm{Mg}_{2+}$ ions have a higher electrode potential than that of $\mathrm{Li}+$ ions $(-2.36$ vs. $-3.04 \mathrm{~V}$ relative to the standard hydrogen electrode potential, respectively).[33-35] This is confirmed by soaking metallic lithium in $0.1 \mathrm{M} \mathrm{Mg}\left(\mathrm{NO}_{3}\right)_{2}$ modified electrolyte for $2 \mathrm{~h}$. We find that the XRD peak around $36.4^{\circ}$ (marked as a purple circle, JCPDS \#35-821) corresponds to metallic $\mathrm{Mg}$ in Figure 7a. In this way, $\mathrm{Li}$ deposition is expected to proceed on the $\mathrm{Mg}$ 


\section{WILEY-VCH}

surface, where a binary Li-Mg alloy can be formed (see XPS data in Figure 7b). This conjecture is supported by the XRD (Figure 7a, red line), where the Mg element was detected on Li metal surface first after immersion in electrolyte for $2 \mathrm{~h}$ while the $\mathrm{Mg} 1 \mathrm{~s}$ peak was shifted toward low binding energy after electrochemical formation step. In detail, the strong XRD peak around $36.1^{\circ}$ (marked as an orange circle, JCPDS \#66-6742) reveals that the formed $\mathrm{Mg}$ undergoes a lithiation process to form a $\mathrm{Li}_{3} \mathrm{Mg}_{7}$ alloy SEI layer. The same phenomenon occurs with $0.05 \mathrm{M} \mathrm{Mg}\left(\mathrm{NO}_{3}\right)_{2}$, as shown in Figure $\mathrm{S} 10$. The formation of a Li$\mathrm{Mg}$ alloy on Li metal surface is in good agreement with previous reports.[26] Herein, the formed $\mathrm{Mg}$ and $\mathrm{Li}-\mathrm{Mg}$ alloy should be thin, because the solubility of the formed $\mathrm{LiNO}_{3}$ (i.e., $\mathrm{Mg}\left(\mathrm{NO}_{3}\right)_{2}+\mathrm{Li}$ electrode $\rightarrow \mathrm{LiNO}_{3}+\mathrm{Mg} / \mathrm{Li}$ electrode $)$ is extremely low, which limits the progress of this spontaneous reaction. This point is very important and interesting, because not only does it result in a protective $\mathrm{Li}-\mathrm{Mg}$ layer, but also it maintains a large proportion of the $\mathrm{Mg}_{2+}$ in the electrolyte to affect the $\mathrm{Li}+$ solvation structure, facilitating $\mathrm{Li}$ deposition.

To gain more insight into the Li-Mg alloy SEI, TOF-SIMs depth profiling was used. A combination of depth profile normalization and $3 \mathrm{D}$ views was used to demonstrate the stratified structure of the SEI with/without $\mathrm{Mg}\left(\mathrm{NO}_{3}\right)_{2}$ additive in the baseline electrolyte. Here, a Cs+ ion beam (40 nA, $3 \mathrm{keV}$ ) was used for sputtering in order to penetrate the SEI (Figure 7c). Note that $\mathrm{CH}_{3+}$ fragments represent the organic part of the SEI induced by decomposition of the organic solvent molecule while $\mathrm{Li}_{2} \mathrm{~F}+$ fragments represent the inorganic part of the SEI. Two salient features can be summarized when the SEI was compared: i) The SEI formed in the $\mathrm{Mg}\left(\mathrm{NO}_{3}\right)_{2}$ modified electrolyte mainly composes of inorganic compounds (i.e., inorganic compounds-dominated SEI). This is confirmed by the strong signal of $\mathrm{Li}_{2} \mathrm{~F}+$ and weak signal of $\mathrm{CH}_{3+}$. In contrast, the signals are converse for the SEI formed in baseline electrolyte (Figure 7c). This demonstrates that the organic components are dominant in SEI (i.e., organic compounds-dominated SEI). These results are consistent well with the characterizations and discussions in XPS (Figure 6); ii) the $\mathrm{Mg}_{2+}$ fragments reside mostly on the SEI surface and 


\section{WILEY-VCH}

the signal is medium, which become weak gradually as etching into the depth of lithium electrode (Figure 7c). The results demonstrate that the Li-Mg alloys can be formed but the amount of reacted $\mathrm{Mg}_{2}+$ is limited due to the low solubility of $\mathrm{LiNO}_{3}\left(\mathrm{Mg}\left(\mathrm{NO}_{3}\right)_{2}+\mathrm{Li}\right.$ electrode $\rightarrow \mathrm{LiNO}_{3}+\mathrm{Mg} / \mathrm{Li}_{\text {electrode }}$, thus giving rise to an $\mathrm{Li}-\mathrm{Mg}$ alloys. Note that the limited reaction caused by the limited solubility of $\mathrm{LiNO}_{3}$ is the process which we expected. This is because an ultrathin $\mathrm{Mg}$ on $\mathrm{Li}$ anode (i.e., $\mathrm{Mg} / \mathrm{Li}$ electrode) can be formed through the limited reaction, and then an ultrathin $\mathrm{Mg}-\mathrm{Li}$ alloy could be formed after the following conversion. Thus, the addition of $\mathrm{Mg}_{2}+\mathrm{NO}_{3}$ - is good for forming the inorganic compounds-dominated SEI and Li$\mathrm{Mg}$ alloys, which can protect the lithium metal and facilitate the transportation of $\mathrm{Li}+$ for the plating/stripping.

\subsection{Electrochemical performance tested under realistic condition}

We further studied battery performance when we reduced the E/C ratio from 27 to 5 in a pouch-type battery (Figure 8a). This is because the Li $\mid$ NCMA73 battery operating in a flooded electrolyte condition could reduce the specific energy density of practical LMBs. Although development of LMB using commercial carbonate-based electrolytes has made great progress in recent years, only few researches has been considered on scale-up LMB systems. In addition, there was also a lack of approaching about electrolyte and lithium metal anode amount control for high energy density. The pouch-type Li | NCMA73 battery delivers a high initial discharge capacity of $210 \mathrm{mAh} \mathrm{g-1} \mathrm{at} 0.1 \mathrm{C}$ and stable cycling over 250 cycles with a capacity retention of $95 \%$. This result demonstrates that the $\operatorname{Mg}\left(\mathrm{NO}_{3}\right)_{2}$ modified electrolytes can satisfy practical applications even under constrained conditions. Furthermore, the proposed strategy demonstrated high compatibility under extremely rigorous condition, very lean electrolyte (E/C ratio 3$)$ and a thin Li metal anode $(20 \mu \mathrm{m}$, giving an N/P ratio of only 2.0), showing a high initial discharge capacity of $210 \mathrm{mAh} \mathrm{g-1}$ and an unprecedented lifetime of over 100 cycles even under rigorous conditions (Figure 8b). 


\section{WILEY-VCH}

\section{Conclusion}

In this work, for the first time, we propose a new effective solvation strategy in ester-based electrolyte enabled by $\operatorname{Mg}\left(\mathrm{NO}_{3}\right)_{2}$, which can alter the solvation structure of lithium ions and form a stable solid electrolyte interphase on the Li metal surface. The interaction between $\mathrm{Li}+$ and $\mathrm{NO}_{3}$ - is preferable, and thus, the $\mathrm{NO}_{3}$ - may replace some of the solvent molecules within the first solvation shell. In addition, $\mathrm{Mg}_{2+}$ ions can coordinate with the solvent, which would also reduce the number of solvent molecules surrounding the $\mathrm{Li}_{+}$. Such changes in the solvation sheath of lithium ions results in a decrease of solvent decomposition as well as an increase in $\mathrm{LiF}$ and $\mathrm{LiN}_{\mathrm{x}} \mathrm{O}_{\mathrm{y}}$ concentration in the SEI for lithium metal protection. In addition, the $\mathrm{Mg}_{2+}$ ions are reduced to $\mathrm{Mg}$ metal via spontaneous chemical reaction on the $\mathrm{Li}$ metal surface and subsequently form a lithiophilic Li-Mg alloy, suppressing the dendritic growth of Li. As a result, dendrite-free Li plating, high coulombic efficiency, and ultra-long lifespan can be successfully achieved. Our experiments performed with pouch type batteries under more severe test conditions than previous studies (lower N/P ratio \& higher C-rate) delivered comparable cycling performance. This work highlights that small changes via simple modulation of ester-based electrolytes with $\mathrm{Mg}\left(\mathrm{NO}_{3}\right)_{2}$ additives have great potential for the use of LMBs in practice.

\section{Experimental Section}

Electrolyte Preparation: LiTFSI, LiDFOB, and $\mathrm{Mg}\left(\mathrm{NO}_{3}\right)_{2}$ were dried under vacuum at $120{ }^{\circ} \mathrm{C}$ using a vacuum oven. LiPF6 was used without pretreatment. EMC and FEC were purified twice using vacuum-dried $4 \AA$ molecular sieves. The baseline electrolyte was $0.8 \mathrm{M}$ LiTFSI, 0.2 M LiDFOB, and 0.05 M LiPF6 dissolved in a solvent mixture of EMC and FEC in a 3:1 volume ratio. The electrolytes containing additive were prepared by adding $0.05 \mathrm{M}$ or $0.1 \mathrm{M} \mathrm{Mg}\left(\mathrm{NO}_{3}\right)_{2}$ into the baseline electrolyte. The moisture content in the electrolytes was less than 10 ppm, as determined by titrating with a KF titrator (C20, Mettler Toledo). 


\section{WILEY-VCH}

Cathode Preparation: Spherical full concentration gradient [Ni0.75Co0.10Mn0.15](OH)2 precursor was synthesized via a co-precipitation method. In order to obtain the layered oxide $\mathrm{Li}\left[\mathrm{Ni} 0.73 \mathrm{Co} .10 \mathrm{Mn} 0.15 \mathrm{Al}_{0.02} \mathrm{O}_{2}\right.$ (NCMA73) cathode materials, the obtained precursors were mixed with $\mathrm{LiOH} \cdot \mathrm{H}_{2} \mathrm{O}$ and $\mathrm{Al}(\mathrm{OH}) 3 \cdot 3 \mathrm{H}_{2} \mathrm{O}(\mathrm{Li}:(\mathrm{Ni}+\mathrm{Co}+\mathrm{Mn}): \mathrm{Al}=1.01: 0.98: 0.02$ molar ratio) and then calcined at $790{ }^{\circ} \mathrm{C}$ for $15 \mathrm{~h}$ under an oxygen gas flow. The cathode was composed of $90 \%$ obtained NCMA73 active material, 5.5\% conducting material and $4.5 \%$ binder on an $\mathrm{Al}$ foil current collector4. The loading level of cathode was $\sim 12.0 \mathrm{mg} \mathrm{cm}-2$.

Electrochemical measurements: For the Li depositing/stripping test, Li | Li symmetric cells and $\mathrm{Li} \mid \mathrm{Cu}$ asymmetric cells were fabricated with $16 \pi \mathrm{Li}$ metal foil and $\mathrm{Cu}$ foil, respectively, and the tests were conducted using VMP3 (Bio-Logic) instruments set for galvanostatic cycling with a current density of $1.8 \mathrm{~mA} \mathrm{~cm}-2$. The amount of electrolyte used was $100 \mu \mathrm{L}$ per cell. LMBs were prepared with FCG73 cathode and a Li metal foil $(200 \mu \mathrm{m})$ as an anode with prepared electrolytes $(100 \mu \mathrm{L}$ per battery). We also fabricated pouch-type batteries $(3 \mathrm{~cm}$ $\times 5 \mathrm{~cm}$ ) with $0.2 \mathrm{~g}$ and with $1 \mathrm{~g}$ electrolyte. Before regular galvanostatic cycling test, four step-formation cycles were carried out at $0.09,0.18,0.36$, and $0.9 \mathrm{~mA} \mathrm{~cm}-2$. Regular cycling tests were performed at constant charge and discharge currents of $1.8 \mathrm{~mA} \mathrm{~cm}-2$ and $5.4 \mathrm{~mA}$ $\mathrm{cm}-2$, respectively, with $2.7-4.3 \mathrm{~V}$ (vs. $\mathrm{Li} / \mathrm{Li}_{+}$) cut-off potential at $30{ }^{\circ} \mathrm{C}$. The rate capability was also tested at various current densities ranging from 0.1 to $9 \mathrm{~mA} \mathrm{~cm}-2$. The pouch-type $\mathrm{Li}$ | NCMA73 battery was tested under relatively low current rate condition (charge: $0.5 \mathrm{C}$ and discharge: $2 \mathrm{C}$, EC ratio 27 and 5; charge: $0.5 \mathrm{C}$ and discharge: $0.3 \mathrm{C}$, EC ratio 3) because scaled-up batteries involve a non-uniform distribution of the electric field during cycles, which usually induces a rapid $\mathrm{Li}$ degradation and dendritic growth of $\mathrm{Li}$ on the $\mathrm{Li}$ anode surface.

Characterization: The solvation structure of electrolytes was analyzed using Nuclear Magnetic Resonance (NMR, Agilent Technologies VNMRS 600MHz) and Raman (Renishaw) spectroscopy. The morphology of the deposited Li was determined by focused ion 


\section{WILEY-VCH}

beam-field emission scanning electron microscope (FIB-FESEM, FEI SCIOS) and extreme high-resolution scanning electron microscopy (FE-SEM, FEI Verios G4 UC). The chemical composition of the anode was characterized by X-ray diffraction pattern (XRD, EMPYREAN), time-of-flight secondary ion mass spectrometry (TOF-SIMS, ION-TOF TOFSIMS 5.5) and X-ray photoelectron spectroscopy (XPS, K-alpha plus Thermo). For characterizing the cycled electrodes, the batteries were disassembled and washed with dimethyl carbonate (DMC, Deajung) inside an Ar-filled glove box.

Binding Energy calculations: The complex consisting of FEC or EMC and Lithium cation was firstly optimized using the PBE0 level [36] of density functional theory (DFT) calculations with the DEF2TZVP basis set[37] implemented in the Gaussian09 package[38]. Thereafter, the binding energy was calculated at the second order of Moller-Plesset perturbation theory (MP2) with the same DEF2TZVP basis set. The basis set superposition error (BSSE) was corrected using the "counterpoise" keyword in the Gaussian09 package.

Classical Molecular Dynamics (MD) simulations: The systems for $\mathrm{Li} / \mathrm{Mg}$ salts in the mixture electrolytes were constructed with a ratio of $\mathrm{Li}:$ EMC $:$ FEC $:$ TFSI $:$ DFOB $: \mathrm{PF}_{6}=1: 7.3$ : $3.5: 0.8: 0.2: 0.1$ and $\mathrm{Li}: \mathrm{Mg}: \mathrm{EMC}: \mathrm{FEC}: \mathrm{TFSI}: \mathrm{DFOB}: \mathrm{PF} 6: \mathrm{NO}_{3}=1: 0.1: 7.3: 3.5:$ $0.8: 0.2: 0.1: 0.2$. The empirical parameters were obtained from previous publications, [39-41] and the missing parameters were obtained by employing the AMBER GAFF method.[42] During the simulation, all the bonds were constrained using the SHAKE algorithm. We firstly equilibrated the systems within the NPT ensemble at $1 \mathrm{~atm}, 300 \mathrm{~K}$ for $20 \mathrm{~ns}$, and the last $5 \mathrm{~ns}$ trajectory was used to calculate the averaged volume. Then, the systems were further equilibrated in the NVT ensemble at $300 \mathrm{~K}$ for another $30 \mathrm{~ns}$. Thereafter, we put the configurations onto the $\mathrm{Cu}(100)$ facets, with the surface atoms carrying 0.05 e to mimic the negative electrode. The simulations were continued for another $10 \mathrm{~ns}$ to observe the trend. 


\section{WILEY-VCH}

\section{Supporting Information}

Supporting Information is available from the Wiley Online Library or from the author.

\section{Acknowledgements}

This work was mainly supported by a Human Resources Development Program (No. 20184010201720) of a Korea Institute of Energy Technology Evaluation and Planning (KETEP) grant, funded by the Ministry of Trade, Industry and Energy of the Korean government. This work also supported by National Research Foundation of Korea (NRF) grant funded by the Korea government Ministry of Education and Science Technology (MEST) (NRF-2018R1A2B3008794).

Received: ((will be filled in by the editorial staff))

Revised: ((will be filled in by the editorial staff))

Published online: ((will be filled in by the editorial staff))

\section{References}

[1] Y. Guo, H. Li and T. Zhai, Adv. Mater. 2017, 29, 1700007

[2] Q. Zhang, K. Wang, X. Wang, Y. Zhong, M. Liu, X. Liu, K. Xu, W. Fan, L. Yu and W. Li, ACS Appl. Mater. Interfaces 2019, 11, 20854.

[3] J. Alvarado, M. A. Schroeder, T. P. Pollard, X. F. Wang, J. Z. Lee, M. H. Zhang, T. Wynn, M. Ding, O. Borodin, Y. S. Meng and K. Xu, Energ. Environ. Sci. 2019, 12, 780.

[4] S. H. Lee, J. Y. Hwang, S. J. Park, G. T. Park and Y. K. Sun, Adv. Funct. Mater. 2019, 29, 1902496.

[5] D. Lin, Y. Liu, Z. Liang, H. W. Lee, J. Sun, H. Wang, K. Yan, J. Xie and Y. Cui, Nat. Nanotechnol. 2016, 11, 626.

[6] H. Zhang, G. G. Eshetu, X. Judez, C. Li, L. M. Rodriguez-Martinez and M. Armand, Angew. Chem. Int. Ed. 2018, 57, 15002.

[7] X. B. Cheng, R. Zhang, C. Z. Zhao and Q. Zhang, Chem. Rev. 2017, 117, 10403.

[8] C. Yan, X. Q. Zhang, J.-Q. Huang, Q. Liu and Q. Zhang, Trends in Chem. 2019, 1, 693.

[9] C. Fang, X. Wang and Y. S. Meng, Trends in Chem. 2019, 1, 152.

[10] S. R. Chen, C. J. Niu, H. Lee, Q. Y. Li, L. Yu, W. Xu, J. G. Zhang, E. J. Dufek, M. S. Whittingham, S. Meng, J. Xiao and J. Liu, Joule 2019, 3, 1094.

[11] K. N. Wood, M. Noked and N. P. Dasgupta, ACS Energ. Lett. 2017, 2, 664.

[12] J. Y. Hwang, S.-J. Park, C. S. Yoon and Y. K. Sun, Energ. Environ. Sci. 2019, 12, 2174.

[13] S. Li, M. Jiang, Y. Xie, H. Xu, J. Jia and J. Li, Adv. Mater. 2018, 30, 1706375.

[14] H. Zhao, D. N. Lei, Y. B. He, Y. F. Yuan, Q. B. Yun, B. Ni, W. Lv, B. H. Li, Q. H. Yang, F. Y. Kang and J. Lu, Adv. Energy Mater. 2018, 8, 1800266. 


\section{WILEY-VCH}

[15] G. H. Yang, J. D. Chen, P. T. Xiao, P. O. Agboola, I. Shakir and Y. X. Xu, J. of Mater. Chem. A 2018, 6, 9899.

[16] A. C. Kozen, C. F. Lin, O. Zhao, S. B. Lee, G. W. Rubloff and M. Noked, Chem. Mater. 2017, 29, 6298 .

[17] Y. Liu, D. Lin, P. Y. Yuen, K. Liu, J. Xie, R. H. Dauskardt and Y. Cui, Adv. Mater. 2017, $29,1605531$.

[18] X. Q. Zhang, X. Chen, L. P. Hou, B. Q. Li, X. B. Cheng, J. Q. Huang and Q. Zhang, ACS Energy Lett. 2019, 4, 411.

[19] X. Q. Zhang, X. Chen, X. B. Cheng, B. Q. Li, X. Shen, C. Yan, J. Q. Huang and Q. Zhang, Angew. Chem. - Int. Ed. 2018, 57, 5301.

[20] C. Yan, Y. X. Yao, X. Chen, X. B. Cheng, X. Q. Zhang, J. Q. Huang and Q. Zhang, Angew. Chem.- Int. Ed. 2018, 57, 14055.

[21] Z. L. Brown, S. Heiskanen and B. L. Lucht, J. Electrochem. Soc. 2019, 166, A2523.

[22] Y. Yang, D. M. Davies, Y. Yin, O. Borodin, J. Z. Lee, C. Fang, M. Olguin, Y. Zhang, E. S. Sablina, X. Wang, C. S. Rustomji and Y. S. Meng, Joule 2019, 3, 1986.

[23] M. S. Kim, J.-H. Ryu, Deepika, Y. R. Lim, I. W. Nah, K.-R. Lee, L. A. Archer and W. Il Cho, Nat. Energy 2018, 3, 889.

[24] S. J. Park, J. Y. Hwang, C. S. Yoon, H. G. Jung and Y. K. Sun, ACS Appl. Mater. Interfaces 2018, 10, 17985.

[25] X. Shangguan, G. Xu, Z. Cui, Q. Wang, X. Du, K. Chen, S. Huang, G. Jia, F. Li, X. Wang, D. Lu, S. Dong and G. Cui, Small 2019, 15, e1900269.

[26] W. Liu, R. Guo, B. X. Zhan, B. Shi, Y. Li, H. J. Pei, Y. Wang, W. Shi, Z. W. Fu and J. Y. Xie, ACs Appl. Energy Mater. 2018, 1, 1674.

[27] S. J. Park, J. Y. Hwang and Y. K. Sun, J. Mater. Chem. A 2019, 7, 13441.

[28] M. Bai, K. Xie, K. Yuan, K. Zhang, N. Li, C. Shen, Y. Lai, R. Vajtai, P. Ajayan and B. Wei, Adv. Mater. 2018, e1801213.

[29] X. Shen, X. Cheng, P. Shi, J. Huang, X. Zhang, C. Yan, T. Li and Q. Zhang, J. Energy Chem. 2019, 37, 29.

[30] D. M. Kang, N. Hart, J. Koh, L. G. Ma, W. B. Liang, J. Xu, S. Sardar and J. P. Lemmon, Energy Storage Mater. 2020, 24, 618.

[31] X. L. Fan, L. Chen, X. Ji, T. Deng, S. Y. Hou, J. Chen, J. Zheng, F. Wang, J. J. Jiang, K. $\mathrm{Xu}$ and C. S. Wang, Chem 2018, 4, 174.

[32] S. H. Jiao, X. D. Ren, R. G. Cao, M. H. Engelhard, Y. Z. Liu, D. H. Hu, D. H. Mei, J. M. Zheng, W. G. Zhao, Q. Y. Li, N. Liu, B. D. Adams, C. Ma, J. Liu, J. G. Zhang and 


\section{WILEY-VCH}

W. Xu, Nat. Energy 2018, 3, 739.

[33] F. Chu, J. Hu, J. Tian, X. Zhou, Z. Li and C. Li, ACS Appl. Mater. Interfaces 2018, 10, 12678.

[34] M. Shimizu, M. Umeki and S. Arai, Phys. Chem. Chem. Phys. 2018, 20, 1127.

[35] S. Choudhury, Z. Tu, S. Stalin, D. Vu, K. Fawole, D. Gunceler, R. Sundararaman and L. A. Archer, Angew. Chem. - Int. Ed. 2017, 56, 13070.

[36] C. Adamo and V. Barone J. Chem. Phy. 1999, 110, 6158.

[37] F. Weigend, R. Ahlrichs, Phys. Chem. Chem. Phys. 2005, 7, 3297.

[38] M. J. Frisch et al., Gaussian 09, Revision A.02, Gaussian, Inc., Wallingford CT, 2016

[39] S. Li, Z. Cao, Y. Peng, L. Liu, Y. Wang, S. Wang, J.-Q. Wang, T. Yan, X.-P. Gao, D.-Y. Song and P.-W. Shen, J. Phy. Chem. B 2008, 112, 6398.

[40] L. Liu, S. Li, Z. Cao, Y. Peng, G. Li, T. Yan and X.-P. Gao, J. Phy. Chem. C 2007, 111, 12161.

[41] W. L. Jorgensen, D. S. Maxwell and J. Tirado-Rives, J. Am. Chem. Soc. 1996, 118, 11225 .

[42] J. Wang, R. M. Wolf, J. W. Caldwell, P. A. Kollmanand D. A. Case, J. Comp. Chem. 2004, 25, 1157. 
WILEY-VCH

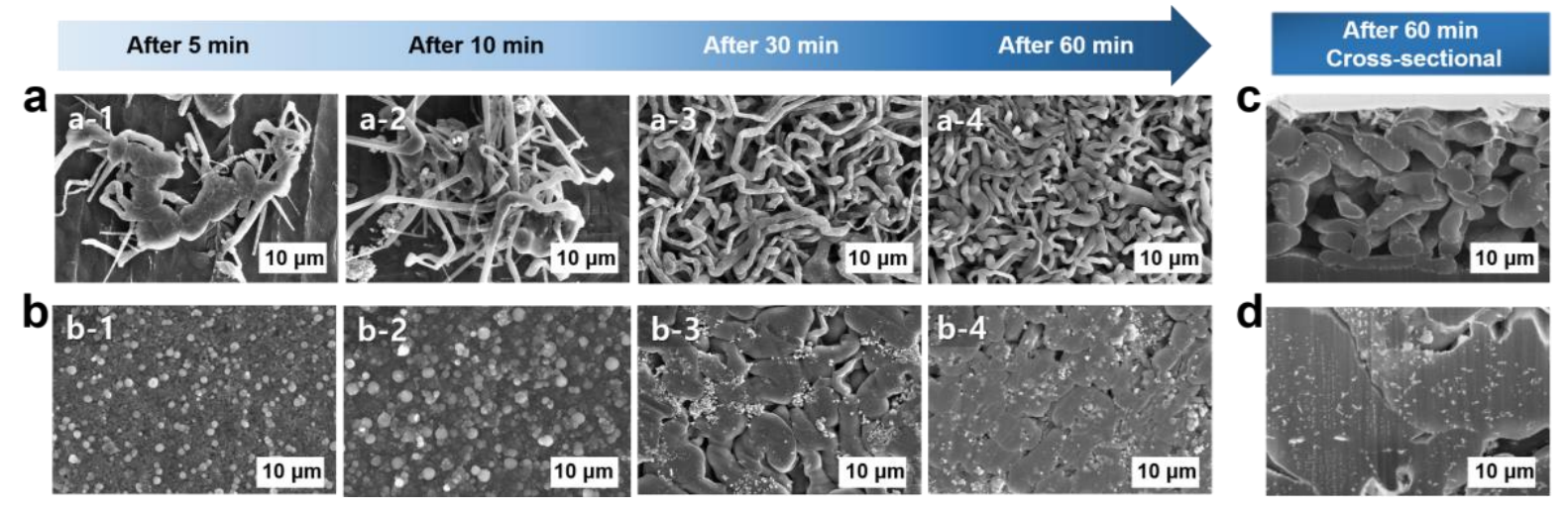

Figure 1 SEM images of deposit Li on Li-metal anode as function of deposit time from 5 to 60 min: (a) with baseline electrolyte and (b) with $0.1 \mathrm{M} \mathrm{Mg}\left(\mathrm{NO}_{3}\right)_{2}$ containing electrolyte. Cross-sectioned SEM images of deposit Li on Li metal after 60 min corresponding to (a-4) and (b-4): (c) with baseline electrolyte and (d) with $0.1 \mathrm{M} \mathrm{Mg}\left(\mathrm{NO}_{3}\right)_{2}$ containing electrolyte. To collect deposit $\mathrm{Li}$, $\mathrm{Li} \mid \mathrm{Li}$ symmetric cells were assembled and tested under constant current density. 

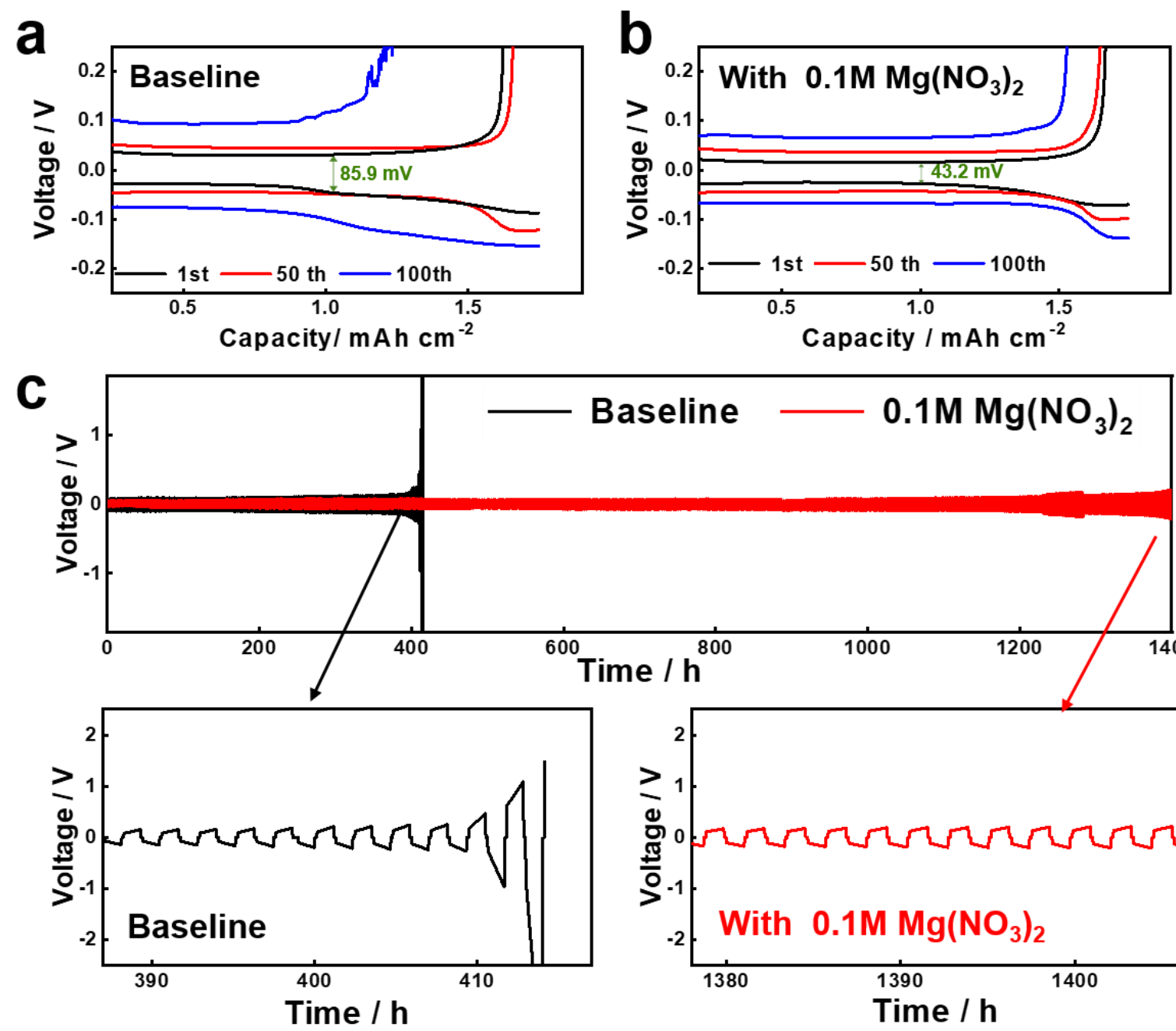

Baseline $-0.1 \mathrm{M} \mathrm{Mg}\left(\mathrm{NO}_{3}\right)_{2}$

Figure 2 Comparison of the Li-metal stability depending on the presence/absence of the $\mathrm{Mg}\left(\mathrm{NO}_{3}\right)_{2}$ additive in the baseline electrolyte. Electrochemical properties of asymmetric $\mathrm{Li}$ | $\mathrm{Cu}$ cells: (a) baseline electrolyte (b) $0.1 \mathrm{M} \mathrm{Mg}\left(\mathrm{NO}_{3}\right)_{2}$ containing electrolyte; (c) $\mathrm{Li}$ | Li cells (black line: baseline electrolyte and red line: $0.1 \mathrm{M} \mathrm{Mg}\left(\mathrm{NO}_{3}\right)_{2}$ containing electrolyte. Both galvanostatic cycling test results of $\mathrm{Li} \mid \mathrm{Cu}$ and $\mathrm{Li} \mid \mathrm{Li}$ cells was tested with different electrolytes at a current density of $1.8 \mathrm{~mA} \mathrm{~cm}-2$ and capacity loading of $1.8 \mathrm{mAh} \mathrm{cm}-2$ 


\section{WILEY-VCH}
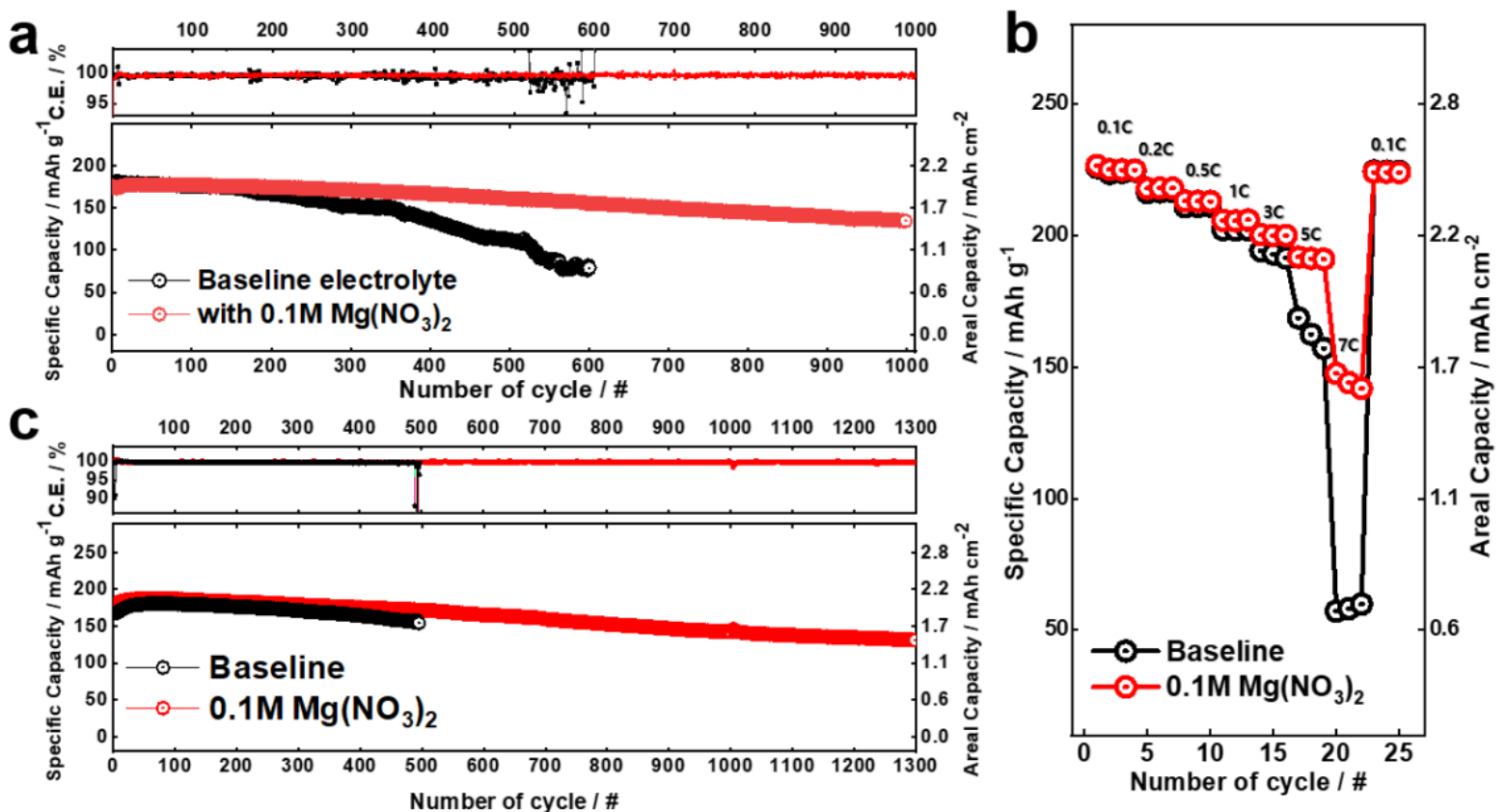

Figure 3 Comparison of the electrochemical performances of Li | NCMA73 batteries with/without $0.1 \mathrm{M} \mathrm{Mg}\left(\mathrm{NO}_{3}\right)_{2}$ additive in the baseline electrolyte (black color: baseline electrolyte and red color: electrolyte with $0.1 \mathrm{M} \mathrm{Mg}\left(\mathrm{NO}_{3}\right)_{2}$. Fundamental electrochemical test using coin-type Li | NCMA73 batteries: (a) long-term cycling test and (b) rate capability test. (c)Long-term cycling test of scaled-up pouch-type Li | NCMA73 batteries with electrolyte to cathode mass ratio (E/C ratio) 27. 
Table 1 Comparison of electrochemical performances of pouch type Li | NCM (and/or A) or $\mathrm{Li}$ | LFP batteries that was tested with carbonate-based electrolyte

\begin{tabular}{|c|c|c|c|c|c|c|}
\hline $\begin{array}{l}\text { Cathode } \\
\text { Material }\end{array}$ & Electrolyte & $\begin{array}{l}\mathrm{N} / \mathrm{P} \\
\text { ratio }\end{array}$ & $\begin{array}{l}\mathrm{E} / \mathrm{C} \\
\text { ratio }\end{array}$ & $\begin{array}{l}\text { Charge } \\
\text { rate }\end{array}$ & $\begin{array}{l}\text { BEST } \\
\text { cycling }\end{array}$ & Ref. \\
\hline NCM811 & $\begin{array}{l}\text { 0.6M LiTFSI, 0.4M LiBOB, } 0.4 \mathrm{M} \mathrm{LiF}, 0.1 \mathrm{M} \\
\mathrm{LiNO}_{3}, 0.05 \mathrm{M} \mathrm{LiPF}_{6} \\
\text { and } 0.03 \mathrm{M} \mathrm{LiBF}_{4} \text { in EC:DMC }(2: 1) \text { with } \\
1 \% \mathrm{FEC}, 2 \% \text { VC and } 3 \% \text { di-2,2,2- } \\
\text { trifluoroethyl carbonate }\end{array}$ & 5 & - & 0.1 & 120 & 23 \\
\hline NCM622 & 1M LiTFSI in EMC/FEC (3:1) & 20 & - & 1 & 100 & 24 \\
\hline LFP & $\begin{array}{l}1 \mathrm{M} \mathrm{LiPF}_{6} \text { and } 1.1 \mathrm{wt} \% \mathrm{LiNO}_{3} \\
\text { in FEC/DMC/DME (3.5:3.5:3) }\end{array}$ & 5 & - & - & 125 & 19 \\
\hline NCM523 & $\begin{array}{l}\text { 0.6LiTFSI +0.4M LiTFPFB+0.05M LiPO }{ }_{2} \mathrm{~F}_{2} \\
\text { in PC/EC/EMC }(1: 1: 3)\end{array}$ & 5 & - & 0.2 & 100 & 25 \\
\hline LCO & 1.2M LiFSI in EC/DMC (3:7) & 30 & - & 0.2 & 100 & 26 \\
\hline NCMA73 & $1 \mathrm{M} \mathrm{LiPF}_{6}$ in EMC/FEC $(3: 1)+0.05 \mathrm{M} \mathrm{LiDFOB}$ & 20 & - & 0.5 & 100 & 27 \\
\hline LFP & $1 \mathrm{M} \mathrm{LiPF}_{6}$ in $\mathrm{EC} / \mathrm{EMC} / \mathrm{DMC}(1: 1: 1)$ & 30 & - & 1 & 200 & 28 \\
\hline LFP & $\mathrm{M} \mathrm{LiPF}_{6}$ in EC/DEC $(1: 1)$ & 4 & - & 0.5 & 100 & 29 \\
\hline $\mathrm{NCM}$ & $1 \mathrm{M} \mathrm{LiPF}_{6}$ in EC/DEC/DMC $(1: 1: 1)$ & 4 & - & 1 & 60 & 30 \\
\hline NCMA73 & 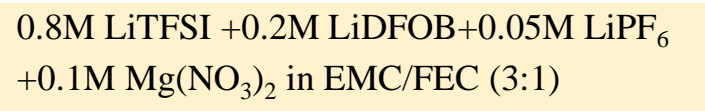 & 20 & 27 & 0.5 & 1300 & $\begin{array}{l}\text { This } \\
\text { work }\end{array}$ \\
\hline
\end{tabular}


WILEY-VCH
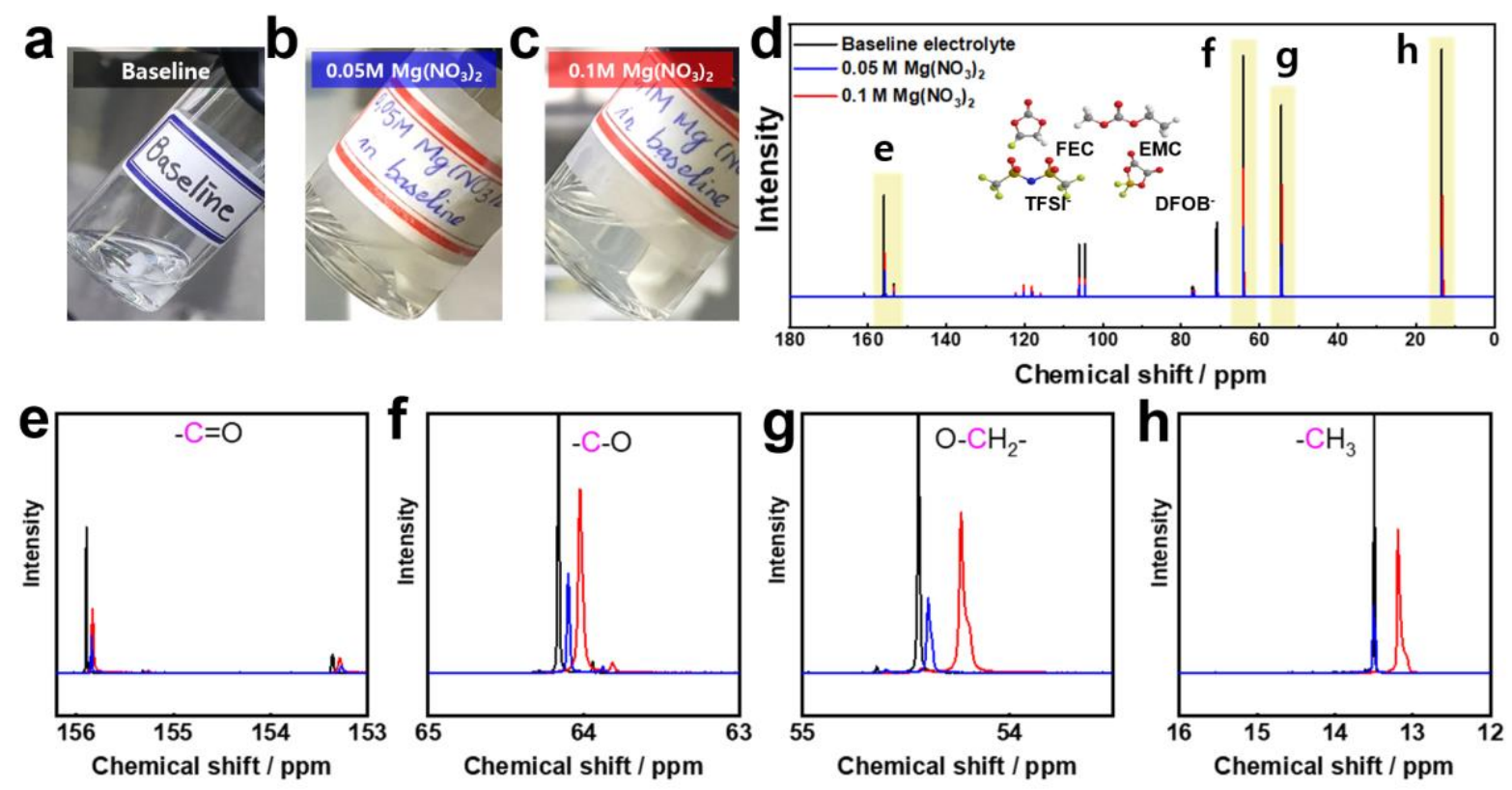

Figure 2 Digital photographs of electrolyte solutions: (a) without (baseline electrolyte), (b) with $0.05 \mathrm{M}$ and (c) $0.1 \mathrm{M} \mathrm{Mg}\left(\mathrm{NO}_{3}\right)_{2}$ additive. ${ }_{13} \mathrm{C}-\mathrm{NMR}$ spectra of various electrolyte solutions: (d) full range spectra and (e-f) magnified NMR spectra of yellow boxes marked in (d); the peaks are corresponded with (e) $-13 \mathrm{C}=\mathrm{O}$ bond, (f) $-13 \mathrm{C}-\mathrm{O},(\mathrm{g}) \mathrm{O}-{ }_{13} \mathrm{CH}_{2}-$ and $(\mathrm{h})-{ }_{13} \mathrm{CH}_{3}$ 
WILEY-VCH

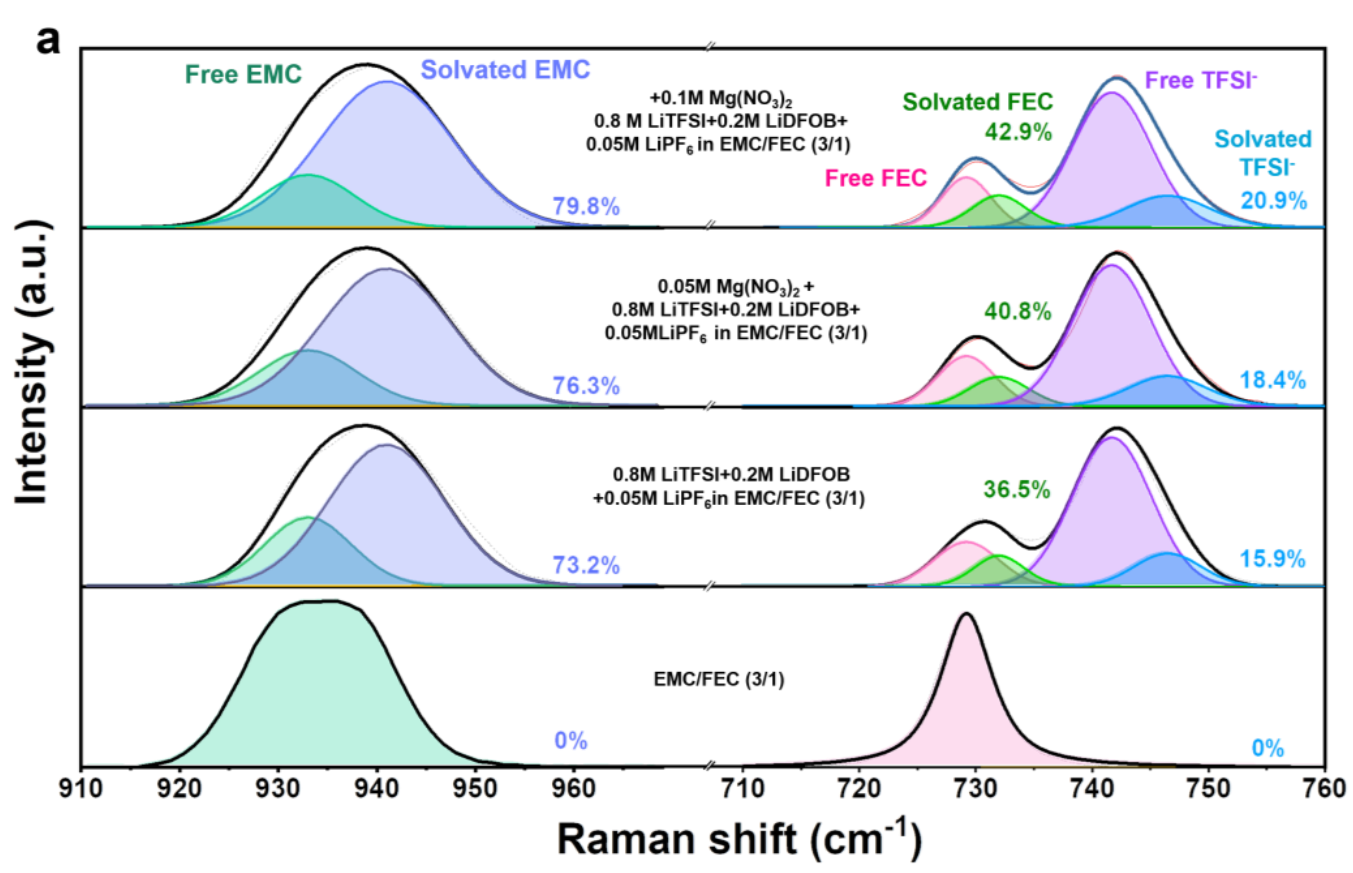

b

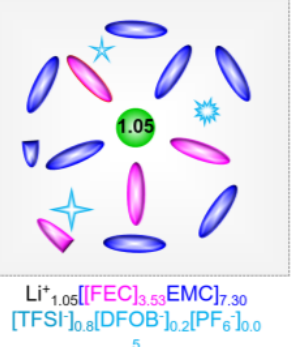

C

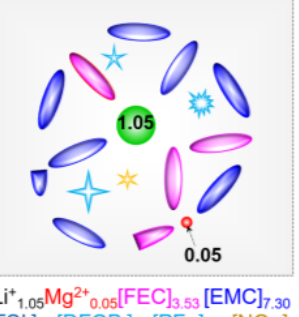

d

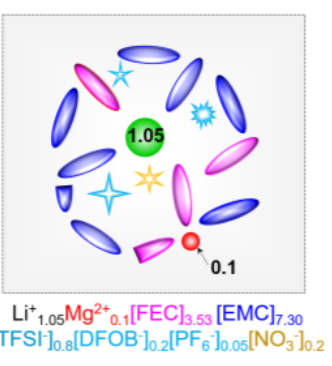

$\mathrm{Li}^{+} \circlearrowright \mathrm{EMC} \circlearrowright \mathrm{FEC}$ \& $\mathrm{TFSI}^{-} \mathrm{DFOB}^{-} \times \mathrm{PF}^{-}$和 $\mathrm{NO}_{3}^{-} \circ \mathrm{Mg}^{2+}$

e
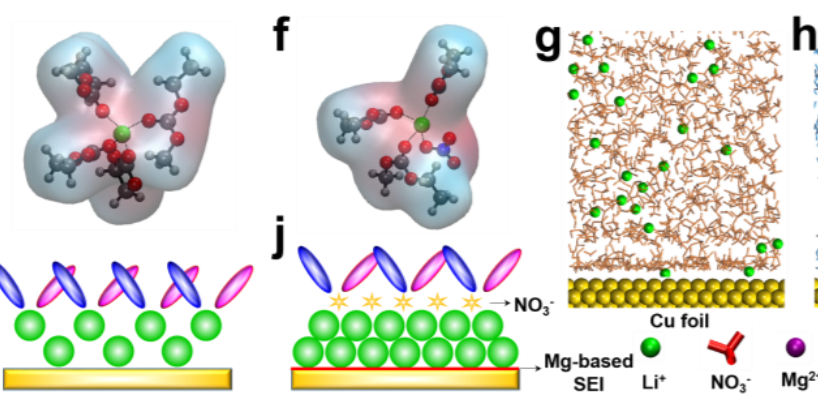

$\mathbf{h}$

(1)
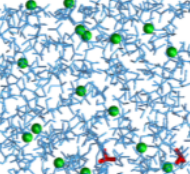

s.

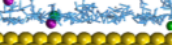

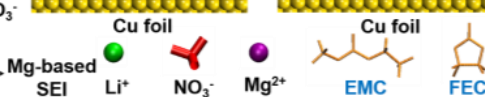

Figure 3 (a) Raman spectra of EMC/FEC (3/1) solvent mixture and electrolyte solutions with varying the concentration of $\mathrm{Mg}\left(\mathrm{NO}_{3}\right)_{2}$ in the baseline electrolyte (0.8 M LiTFSI+0.2 M LiDFOB+0.05 M LiPF6 in EMC/FEC (3/1). Schematic illustration of changes in Li+ solvation structure of the baseline electrolyte by adding by adding $\mathrm{Mg}\left(\mathrm{NO}_{3}\right)_{2}$ additive: (b) without (baseline electrolyte), (c) with $0.05 \mathrm{M}$ and (d) with $0.1 \mathrm{M} \mathrm{Mg}(\mathrm{NO} 3) 2$. Molecular dynamics simulations of $(e, f)$ solvation structure and $(g, h)$ snapshots of the MD simulation boxes about different electrolyte solutions: (e, g) baseline electrolyte and (f, h) $0.1 \mathrm{M} \mathrm{Mg}\left(\mathrm{NO}_{3}\right)_{2}$-containing electrolyte. Schematic illustration of interface between Li metal anode and electrolyte depending on $\mathrm{Mg}\left(\mathrm{NO}_{3}\right)_{2}$ additive: (i) baseline electrolyte and (j) $0.1 \mathrm{M} \mathrm{Mg}\left(\mathrm{NO}_{3}\right)_{2}$-containing electrolyte. 
WILEY-VCH

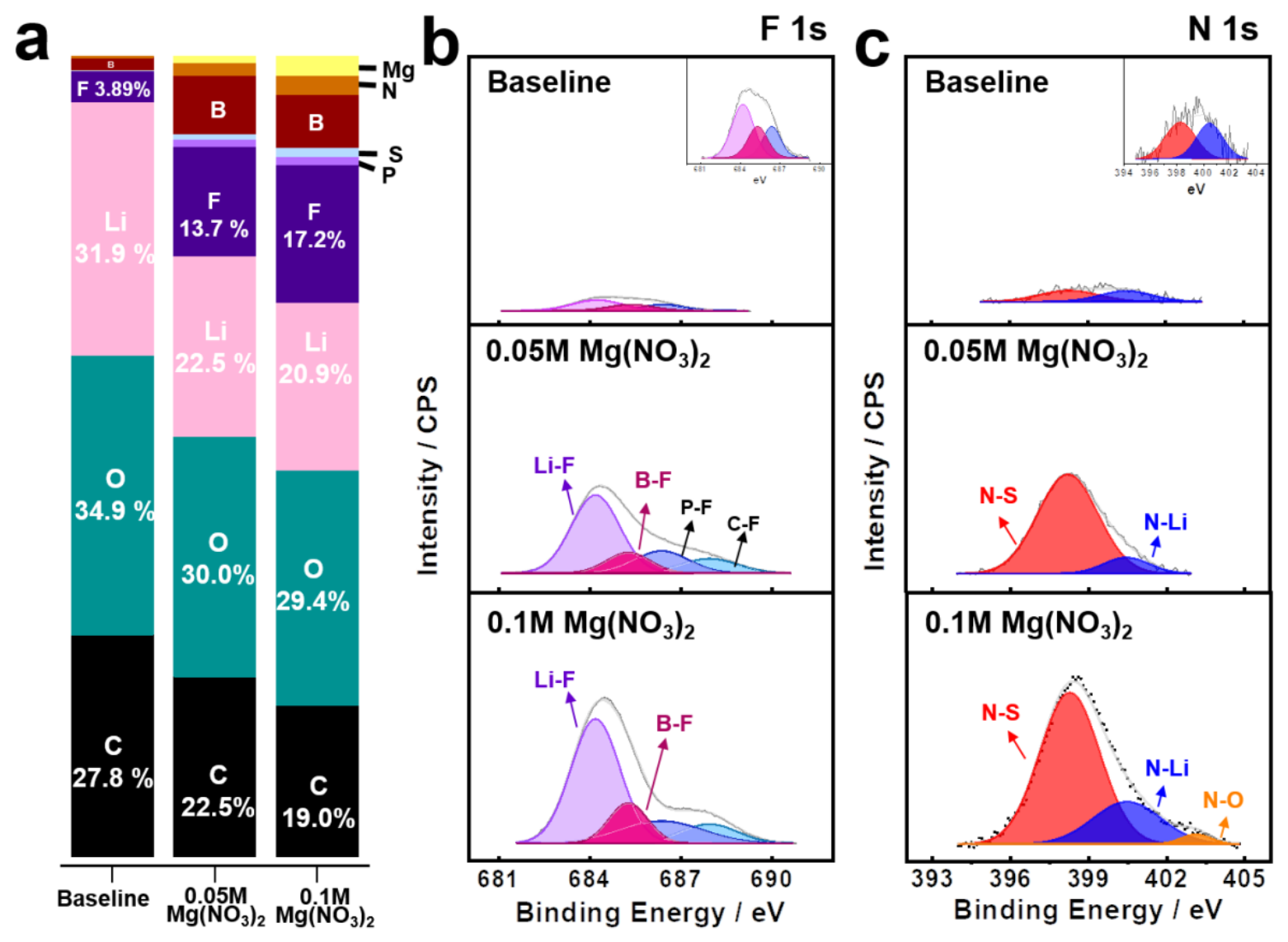

Figure 4 XPS analysis of SEI layer on Li-metal anode depending on electrolyte solutions with varying the concentration of $\mathrm{Mg}\left(\mathrm{NO}_{3}\right)_{2}$ in the baseline electrolyte: (a) Atomic ratio of the element distributions in the SEI layers; (b) F1s spectra and (c) N1s spectra 

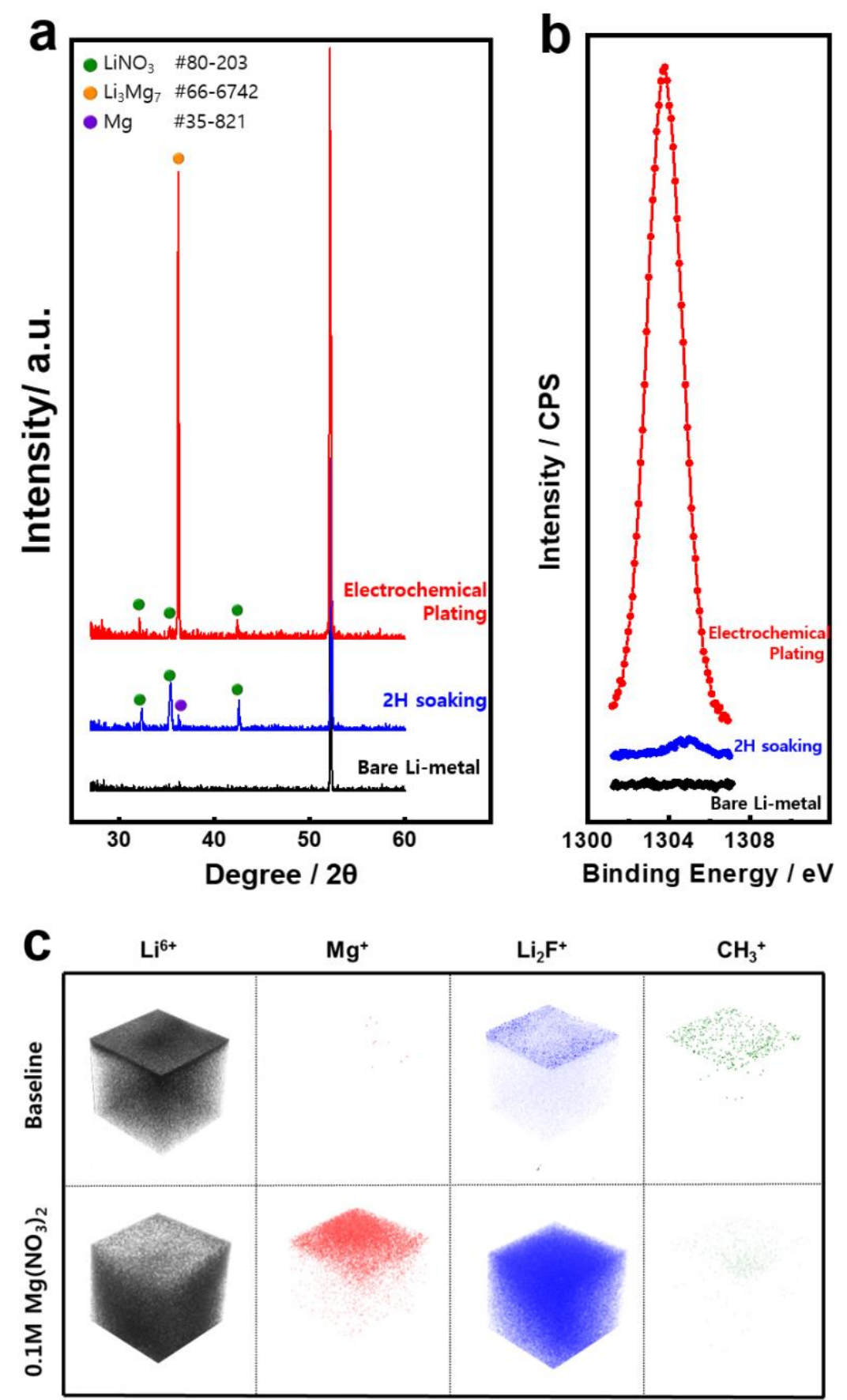

Figure 7 (a) XRD patterns and (b) Mg 1s XPS spectra of Li anode with/without treatment (black line: bare, blue line: after soaking in $0.1 \mathrm{M} \mathrm{Mg}\left(\mathrm{NO}_{3}\right)_{2}$-containing electrolyte and red line: after electrochemical plating process. (c) TOF-SIMs 3D render image of Li surface (represented by the Li6+ fragment) after electrochemical plating process in the baseline and $0.1 \mathrm{M} \mathrm{Mg}\left(\mathrm{NO}_{3}\right)_{2}$ electrolyte. 


\section{WILEY-VCH}
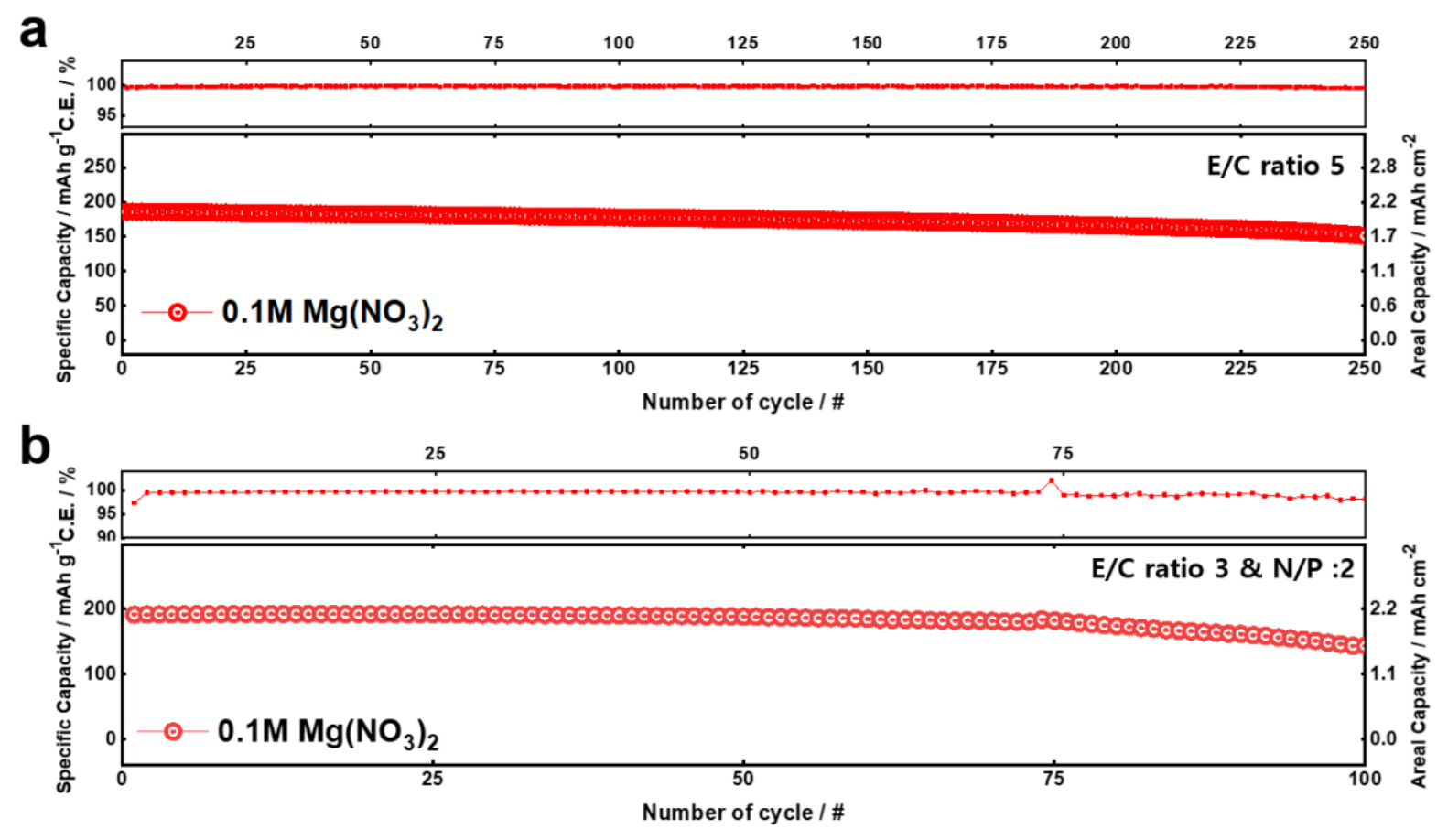

Figure 8 Electrochemical performances of pouch-type Li| NCMA73 batteries tested under realistic condition :(a) E/C ratio 5 and (b)E/C ratio 3 and N/P ratio 2. 


\section{WILEY-VCH}

\section{Table contents of entry}

Unique electrolyte solvation chemistry and lithiophilic SEI layer

Seon Hwa Lee, Jang-Yeon Hwang, Jun Ming, Zhen Cao, Hoang Anh Nguyen, Hun-Gi Jung, Jaekook Kim, and Yang-Kook Sun*

Toward the Sustainable Lithium Metal Batteries with a New Electrolyte Solvation Chemistry

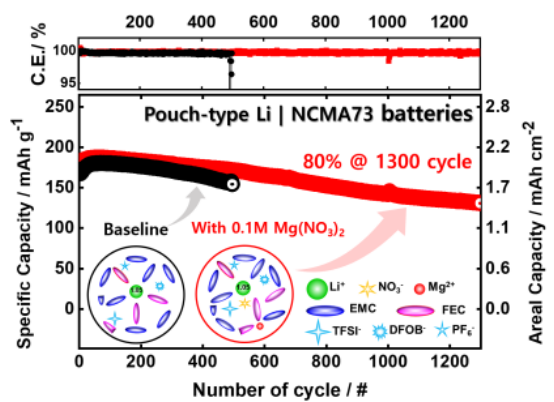

$\mathrm{Mg}(\mathrm{NO})_{3}$, which is firstly introduced as an additive to ester-based electrolytes, not only alter unique solvation structures of Li-ion but also form a lithiophilic Li-Mg alloys on the lithium metals. These synergetic effect enables ensure an unprecedented lifespan over 1300 cycles for a practical pouch-type LMB with high-voltage Ni-rich NCMA73 cathode even under constrained conditions. 


\section{WILEY-VCH}

Copyright WILEY-VCH Verlag GmbH \& Co. KGaA, 69469 Weinheim, Germany, 2016.

\section{Supporting Information}

\section{Toward the Sustainable Lithium Metal Batteries with a New Electrolyte Solvation Chemistry}

Seon Hwa Lee, Jang-Yeon Hwang, Jun Ming, Zhen Cao, Hoang Anh Nguyen, Hun-Gi Jung, Jaekook Kim, and Yang-Kook Sun*

S. H. Lee, H. A. Nguyen, Prof. Y.-K. Sun

Department of Energy Engineering,

Hanyang University,

Seoul 04763, Republic of Korea

Email: yksun@hanyang.ac.kr

Prof. J.-Y. Hwang, Prof. J. Kim

Department of Materials Science and Engineering,

Chonnam National University,

Gwangju, 61186, Republic of Korea

Prof. J. Ming

State Key Laboratory of Rare Earth Resource Utilization,

Changchun Institute of Applied Chemistry, CAS,

Changchun, 130022, P. R. China

Dr. Z. Cao

Physical Sciences and Engineering Division,

King Abdullah University of Science and Technology,

Thuwal 23955-6900, Saudi Arabia

H.-G. Jung

Center for Energy Convergence Research, Green City Technology Institute, Korea Institute of Science and Technology,

Seoul, 136-791, Republic of Korea 


\section{WILEY-VCH}
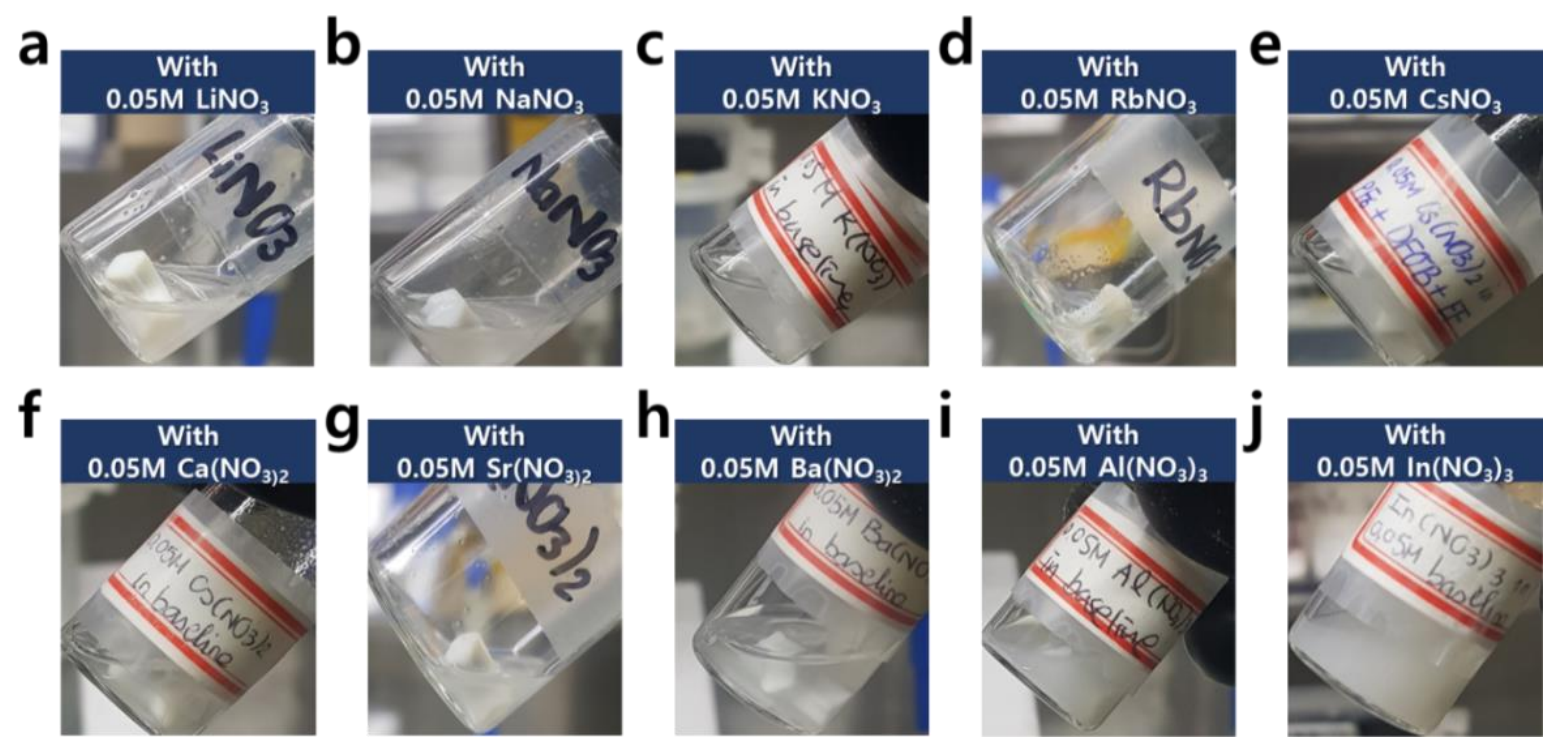

Figure S1. Comparative digital photographs of electrolyte solutions containing $0.05 \mathrm{M}$ (a) LiNO3, (b) $\mathrm{NaNO}_{3}$, (c) $\mathrm{KNO}_{3}$, (d)RbNO3, (e) $\mathrm{CsNO}_{3}$, (f) $\mathrm{Ca}\left(\mathrm{NO}_{3}\right)_{2}$, (g) $\mathrm{Sr}\left(\mathrm{NO}_{3}\right)_{2}$, (h) $\mathrm{Ba}\left(\mathrm{NO}_{3}\right)_{2}$, (i) $\mathrm{Al}\left(\mathrm{NO}_{3}\right)_{3}$, and (j) $\mathrm{In}\left(\mathrm{NO}_{3}\right)_{3}$ additives, repectively. 


\section{WILEY-VCH}
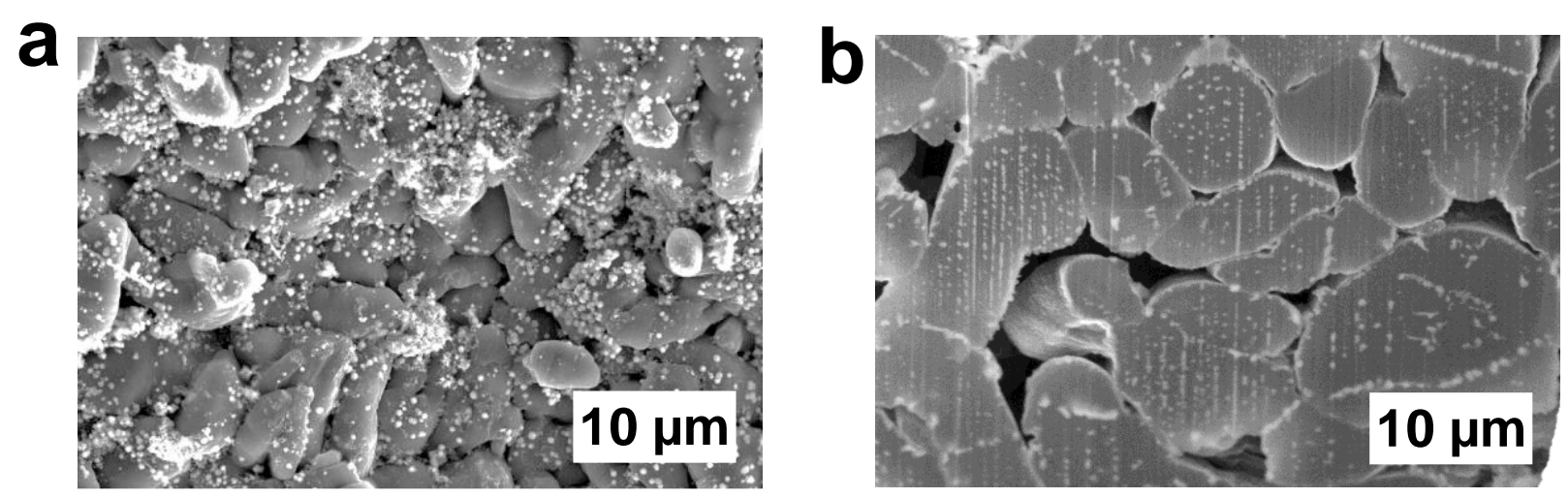

Figure S2. (a) Top view and (b) cross sectional SEM images of deposited Li on Li-metal anode with $0.05 \mathrm{M} \mathrm{Mg}\left(\mathrm{NO}_{3}\right)_{2}$-containing electrolyte. To collect the deposited $\mathrm{Li}, \mathrm{Li} \mid \mathrm{Li}$ symmetric cells were assembled and tested under a constant current density of $1.8 \mathrm{~mA} \mathrm{~cm}-2$ and capacity loading of $1.8 \mathrm{mAh} \mathrm{cm}-2$. 


\section{WILEY-VCH}

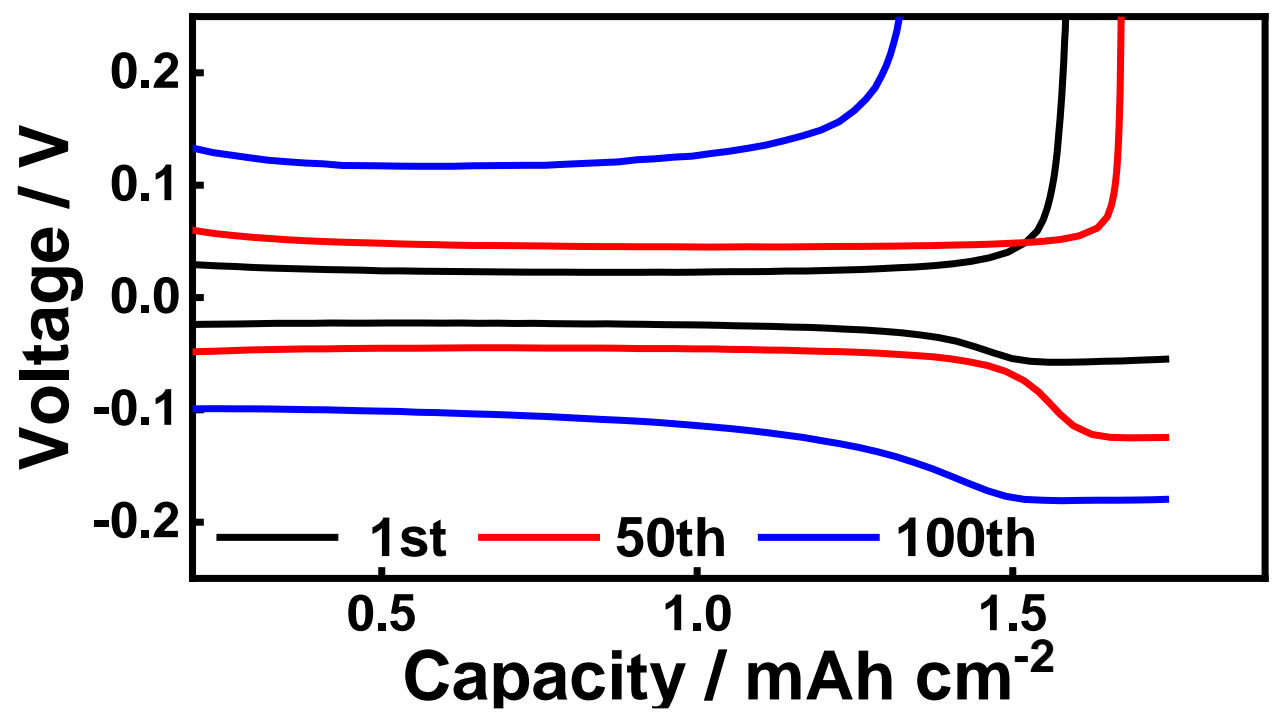

Figure S3. Electrochemical properties of asymmetric $\mathrm{Li} \mid \mathrm{Cu}$ cell tested with $0.05 \mathrm{M}$ $\mathrm{Mg}\left(\mathrm{NO}_{3}\right)_{2}$-containing electrolyte. This cell was tested with different electrolytes at a current density of $1.8 \mathrm{~mA} \mathrm{~cm}-2$ and capacity loading of $1.8 \mathrm{mAh} \mathrm{cm-2.}$ 


\section{WILEY-VCH}

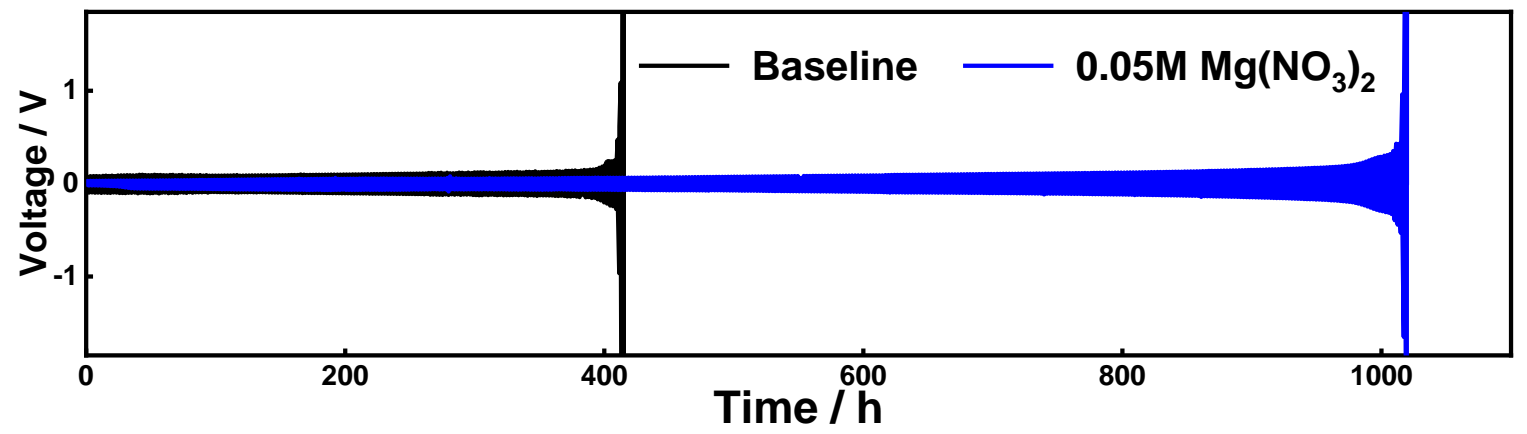

Figure S4. Electrochemical cycling performance for $\mathrm{Li} \mid \mathrm{Li}$ cells (black line: baseline electrolyte and blue line: $0.05 \mathrm{M} \mathrm{Mg}\left(\mathrm{NO}_{3}\right)_{2}$-containing electrolyte). $\mathrm{Li}$ | Li cells were tested with different electrolytes at a current density of $1.8 \mathrm{~mA} \mathrm{~cm}-2$ and capacity loading of 1.8 $\mathrm{mAh} \mathrm{cm}-2$. 


\section{WILEY-VCH}

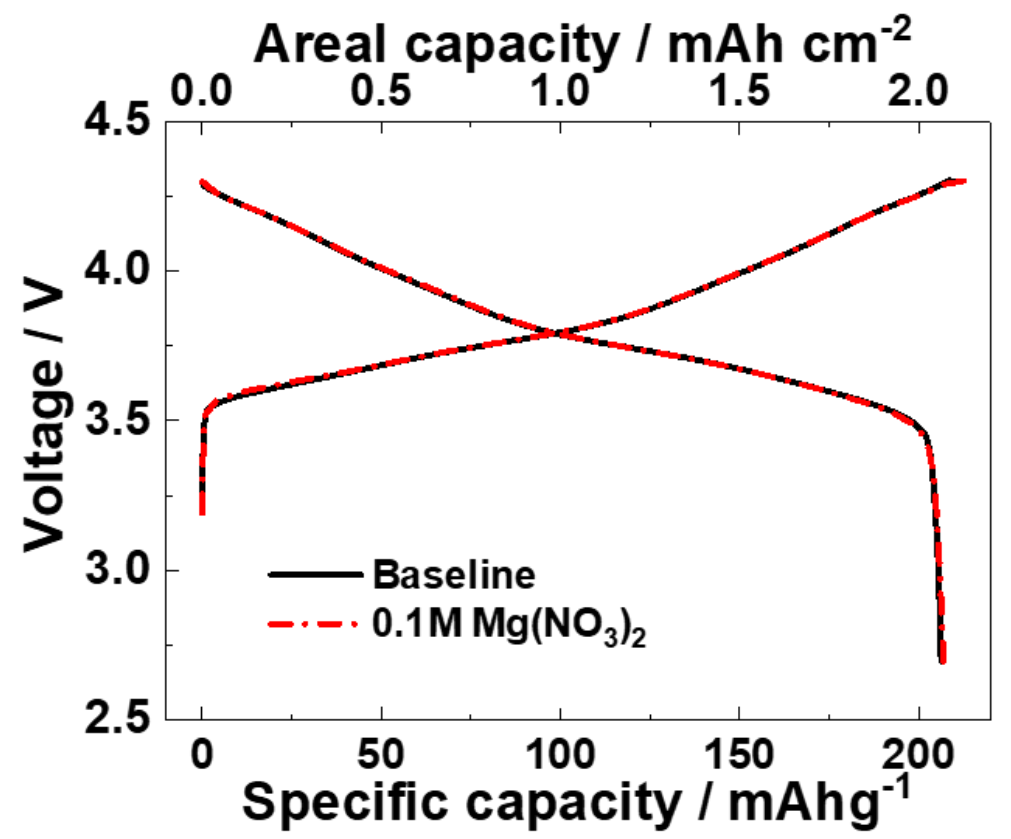

Figure S5. Comparison of the galvanostatic test voltage profile of Li | NCMA73 batteries 1 st cycle with/without $0.1 \mathrm{M} \mathrm{Mg}\left(\mathrm{NO}_{3}\right)_{2}$ additive in the baseline electrolyte (black: baseline electrolyte and red: electrolyte with $\left.0.1 \mathrm{M} \mathrm{Mg}\left(\mathrm{NO}_{3}\right)_{2}\right)$. 


\section{WILEY-VCH}

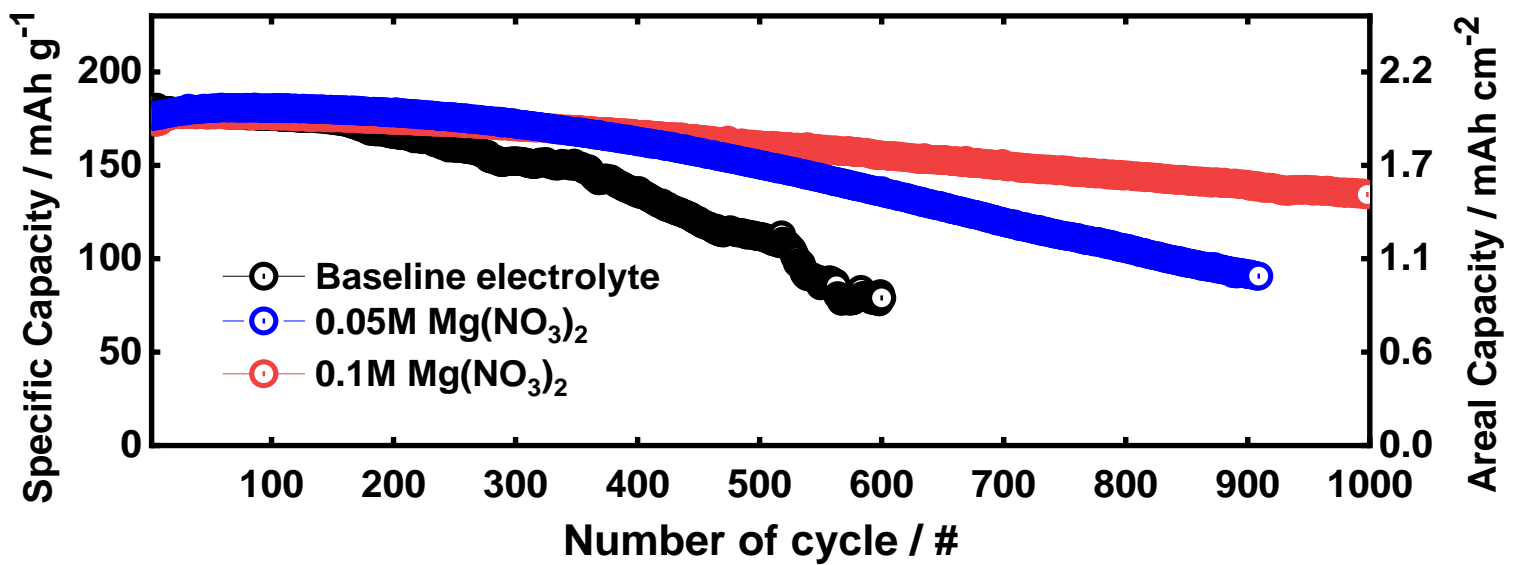

Figure S6. Comparison of the electrochemical performances of coin-type Li | NCMA73 batteries with varying concentration of $\mathrm{Mg}\left(\mathrm{NO}_{3}\right)_{2}$ in the baseline electrolyte. (black: baseline electrolyte, blue: electrolyte with $\left.0.05 \mathrm{M} \mathrm{Mg}\left(\mathrm{NO}_{3}\right)_{2}\right)$ and red: electrolyte with $0.1 \mathrm{M}$ $\left.\mathrm{Mg}\left(\mathrm{NO}_{3}\right)_{2}\right)$. 


\section{WILEY-VCH}

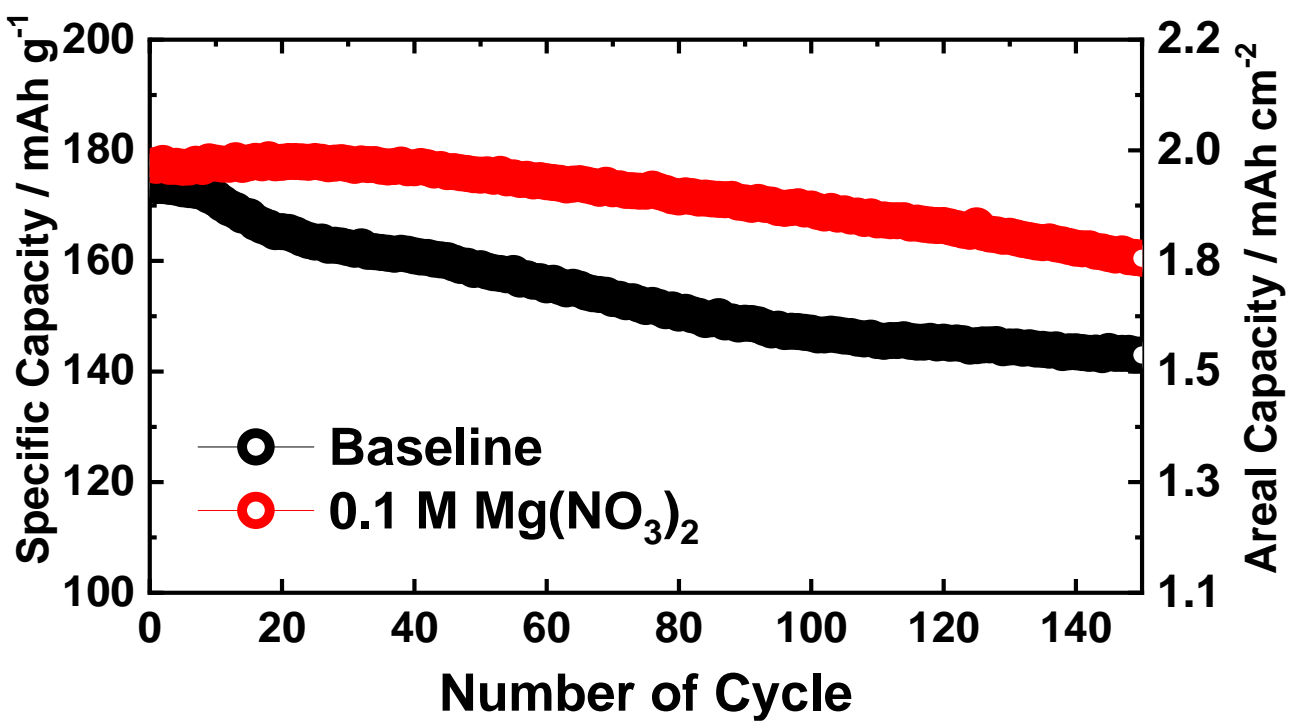

Figure S7. Comparison of the cycling performance of Li/NCMA cells with and without additive $\mathrm{Mg}\left(\mathrm{NO}_{3}\right)_{2}$. All cells were tested in the voltage range of $2.7-4.3 \mathrm{~V}$ at a current density of $4 \mathrm{~mA} \mathrm{~cm}-2$. 


\section{WILEY-VCH}

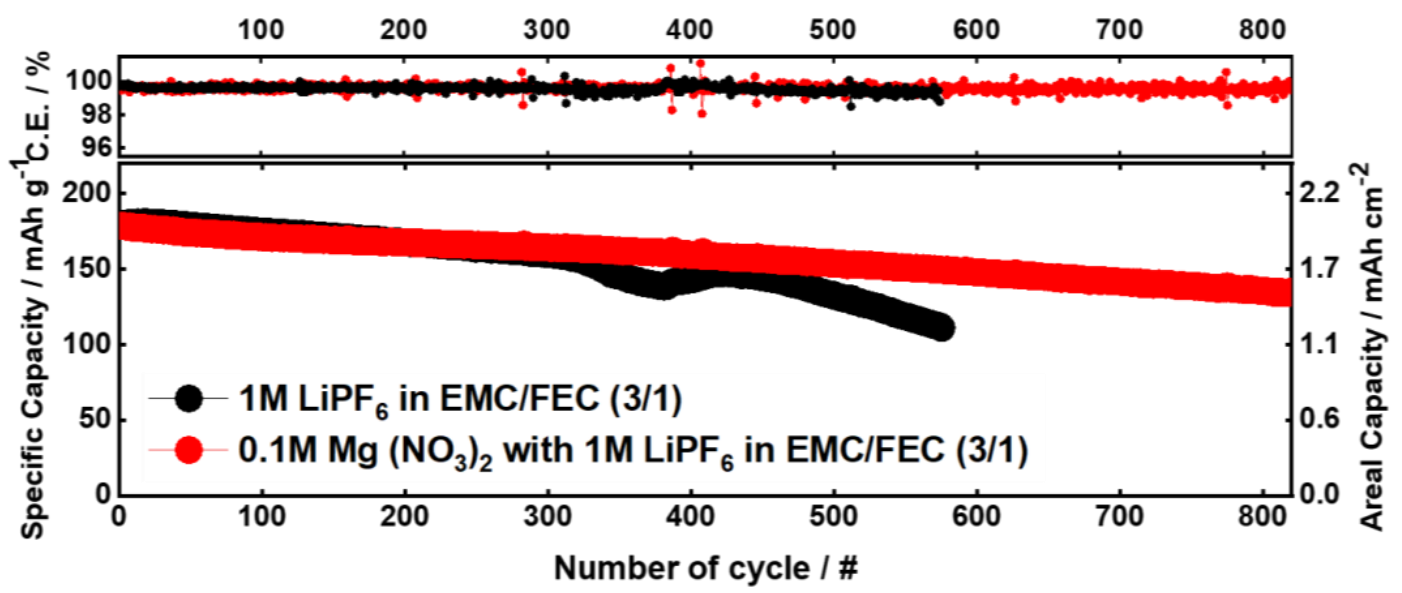

Figure S8. Comparison of the cycling performance of Li/NCMA cells with and without additive $\mathrm{Mg}\left(\mathrm{NO}_{3}\right)_{2}$ in $1.0 \mathrm{M} \mathrm{LiPF} 6$ in $\operatorname{EMC}: \operatorname{FEC}(3: 1, \mathrm{v} / \mathrm{v})$ electrolyte. All cells were tested in the voltage range of $2.7-4.3 \mathrm{~V}$ at a current density of $1.8 \mathrm{~mA} \mathrm{~cm}-2$. 
WILEY-VCH
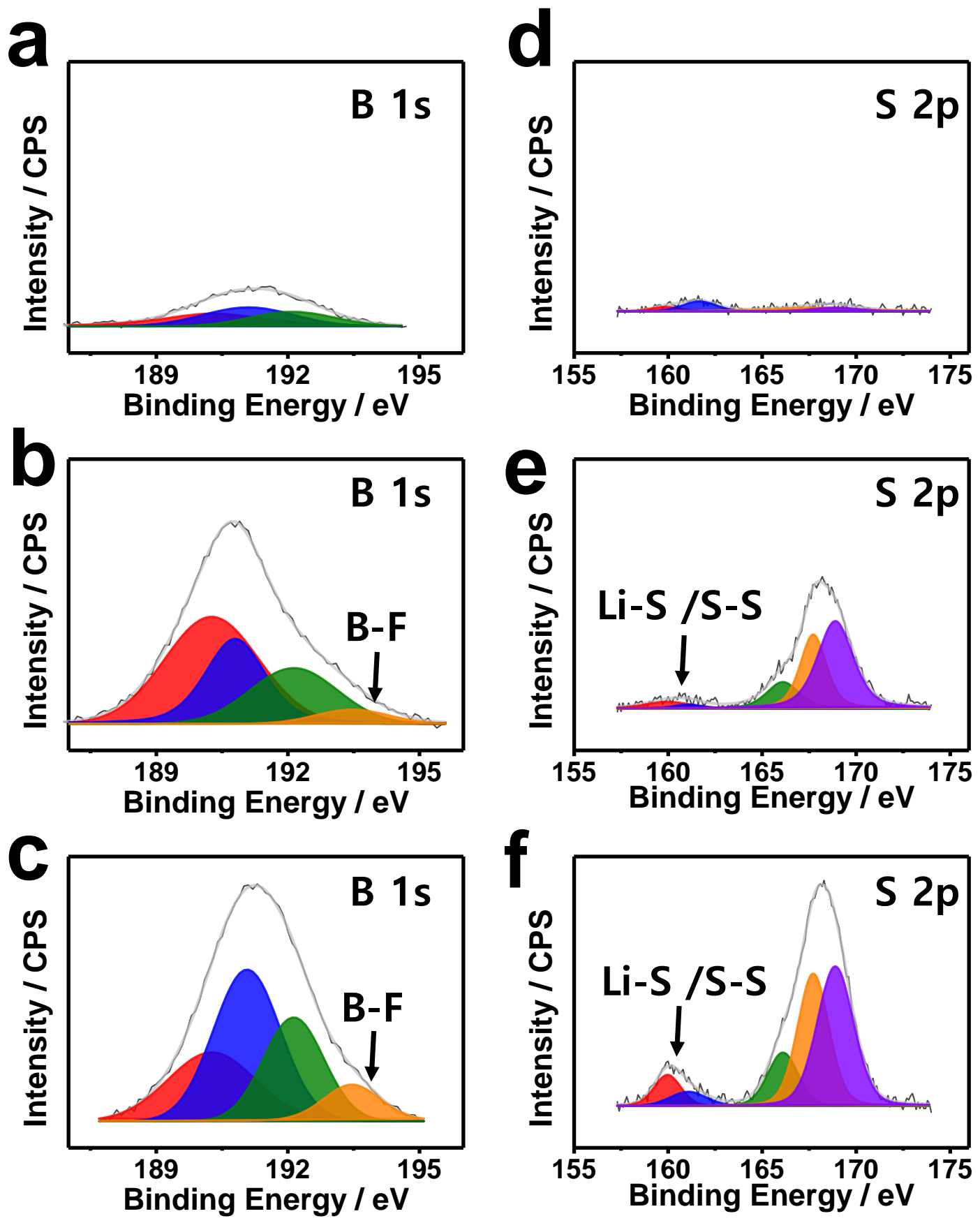

Figure S9. XPS analysis of SEI layer on Li-metal anode depending on electrolyte solutions: (a,d) baseline, (b,e) $0.05 \mathrm{M}$ and (c,f) $0.1 \mathrm{M} \mathrm{Mg}\left(\mathrm{NO}_{3}\right)_{2}$-containing electrolyte; (a-c) B 1s spectra and (d-f) S 2p spectra. 
WILEY-VCH
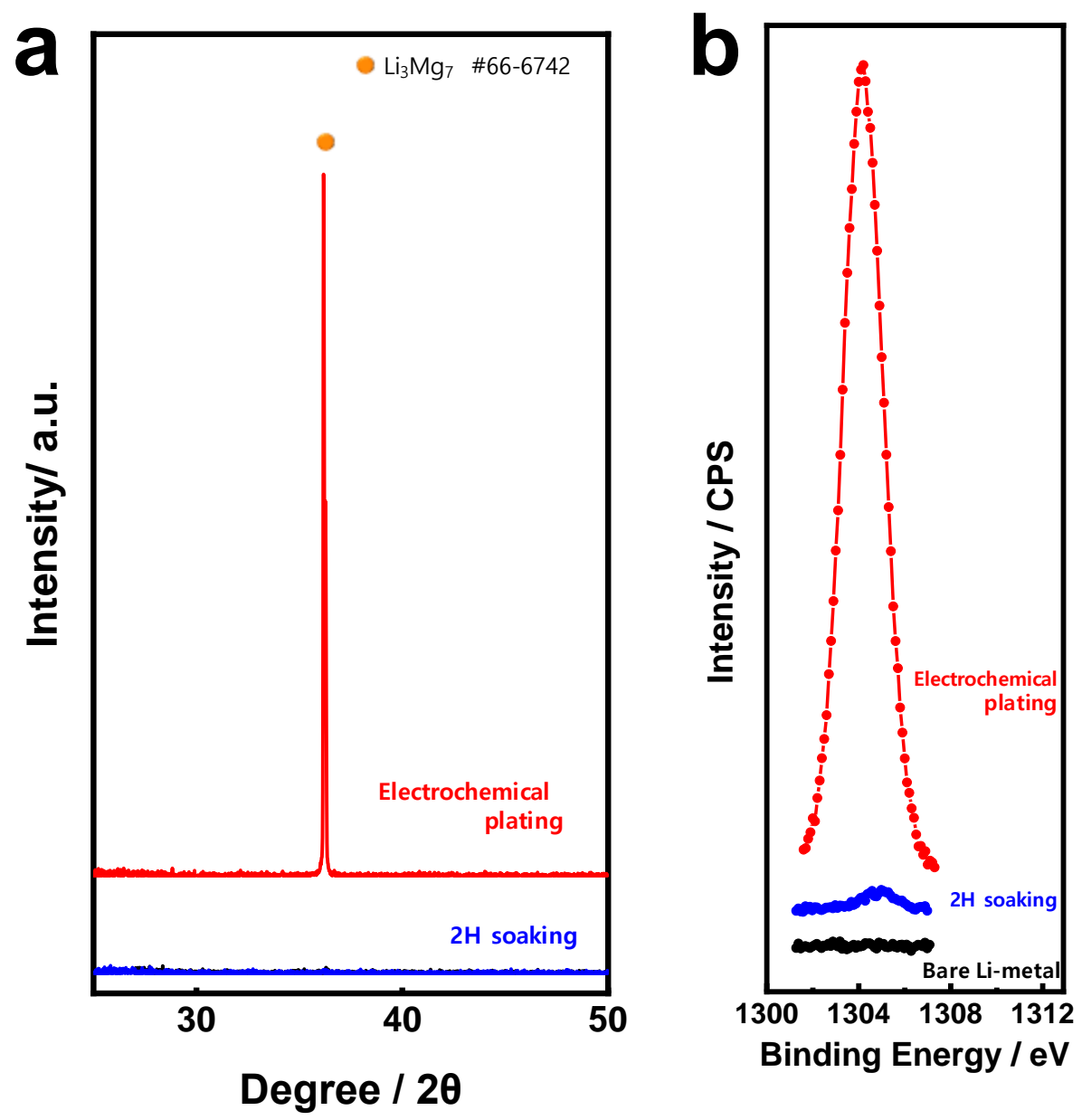

Figure S10. (a) XRD patterns and (b) Mg 1s XPS spectra of Li anode with/without treatment (black: bare, blue: after soaking in $0.05 \mathrm{M} \mathrm{Mg}\left(\mathrm{NO}_{3}\right)_{2}$-containing electrolyte, and red: after electrochemical plating process. 